DOI: $10.19195 / 0080-3626.62 .5$

MAŁGORZATA KORCZYŃSKA-DERKACZ

\title{
Z HISTORII PRASY NAJWIĘKSZYCH ZAKŁADÓW PRZEMYSŁOWYCH WROCŁAWIA I OKOLIC (1946-1990)
}

Definicja i typologia prasy zakładowej z punktu widzenia pełnionych funkcji. Charakterystyka prasy zakładowej w Polsce w latach 1967-1990 (liczba tytułów, częstotliwość, geografia wydawnicza). Funkcjonowanie tego typu prasy na Dolnym Śląsku w świetle dokumentów archiwalnych KW PZPR we Wrocławiu. Charakterystyka 10 tytułów gazet zakładowych wydawanych we Wrocławiu, Brzegu Dolnym i Jelczu-Laskowicach w latach 1954-1990 (cechy formalne, kolegia redakcyjne, tematyka).

SŁOWA KLUCZOWE: gazety zakładowe, prasa partyjna, prasa regionalna i lokalna, Wrocław, województwo dolnośląskie, „Głos Jelcza” „Głos Rokity”, „Elwro”, „Intermoda”, „Ku Nowemu”, „Nasze Problemy”, „Pafawag”, „Polar”, „Żeglarz Odrzański”, „Życie Załogi”

Stan badań nad prasą zakładową w Polsce nie jest zbyt obszerny. Przez długi czas w ogóle nie podejmowano nad nią badań, między innymi z powodu rozproszenia materiału i trudności w dotarciu do niego, ponieważ $\mathrm{w}$ zbiorach bibliotecznych często prasa ta znajdowała się nie w zbiorach czasopism, lecz w oddziałach dokumentów życia społecznego. Prasy zakładowej nie odnotowywała „Bibliografia Czasopism i Wydawnictw Zbiorowych” i późniejsza „Bibliografia Wydawnictw Ciągłych", wydawana przez Instytut Bibliograficzny Biblioteki Narodowej, a w „Ruchu Wydawniczym w Liczbach” (dalej: „RWL”) pojawiła się dopiero w 1968 roku$^{1}$. Wzrost zainteresowania tym typem prasy nastąpił w drugiej połowie lat $70 . \mathrm{XX}$ wieku ${ }^{2}$, kiedy była ona w pełnym rozkwicie.

1 We Wstępie do rocznika 14 z 1968 roku redakcja zaznaczyła, że wprowadza tabele dotyczące gazet zakładowych, mimo iż nie są one odnotowywane w bibliografii narodowej. Są jednak zgodne z decyzjami UNESCO podjętymi na XIII Sesji w Paryżu, 19 listopada 1964 roku, gdzie krajom członkowskim zalecono łączne ujmowanie roczników wydawnictw zbiorowych oraz periodyków. W 1968 roku Polska dopiero przygotowywała się do tych zmian. Gazety zakładowe nie zostały dodane do zbiorowych zestawień dotyczących gazet i czasopism.

${ }_{2}$ Między innymi: J. Turlik-Marecka, J.B. Sobczak, Rola i funkcje prasy zakładowej w Polsce, Kraków 1975; T. Kupis, Prasa zakładowa elementem systemu prasowego, „Prasa Polska” 1977, nr 9, s. 19-21; W. Pisarek, A. Skowroński, A. Świda, Raport o prasie zakładowej, „Zeszyty 
Niniejszy artykuł dotyczy niebadanej do tej pory prasy zakładowej wydawanej we Wrocławiu, Brzegu Dolnym i Jelczu-Laskowicach, gdzie zlokalizowane były duże zakłady przemysłowe (Nadodrzańskie Zakłady Przemysłu Organicznego „Rokita” w Brzegu Dolnym oraz Jelczańskie Zakłady Samochodowe), i które to miejscowości traktowane były jako miasta-satelity związane ze stolicą Dolnego Śląska wręcz organicznie. W tabelach wzięto pod uwagę lata, w których gazety zakładowe były uwzględniane w „RWL”, to jest 1968-1992. Natomiast w odniesieniu do konkretnych tytułów chronologia obejmuje okres od zakończenia drugiej wojny światowej do momentu restrukturyzacji przemysłu na początku lat 90. XX wieku. Analizie poddano wszystkie tytuły i ich pełne zasoby znajdujące się w Bibliotece Uniwersyteckiej we Wrocławiu oraz w Dolnośląskiej Bibliotece Publicznej im. Tadeusza Mikulskiego we Wrocławiu. Wykorzystane zostały także dokumenty archiwalne przechowywane w Archiwum Państwowym we Wrocławiu, w szczególności akta wytworzone przez Komitet Wojewódzki Polskiej Zjednoczonej Partii Robotniczej w latach 1971-1978 oraz wspomniany „RWL”. Wskazane źródła badano przy wykorzystaniu metod analizy zawartości prasy, analizy i krytyki źródeł oraz technik statystycznych.

Termin 'prasa zakładowa' stosowany jest na określenie specyficznego typu prasy, ,wydawanego i finansowanego przez zakłady pracy, kolportowanego po obniżonej cenie lub bezpłatnie, głównie wśród zamkniętego kręgu odbiorców (członków załogi)"3. Zamiennie stosowane określenia 'gazeta zakładowa', 'gazeta fabryczna' (także 'zakładówka', 'mała prasa') mają swoje źródło w powiązaniu z zakładami pracy, aktualnością treści, wyglądem, tytulaturą, ale już nie z częstotliwością, ponieważ prasa ta wydawana bywała jako tygodniki, dwutygodniki, miesięczniki, kwartalniki czy wręcz nieregularnie.

Według Mariana Banaszka do prasy zakładowej „zalicza się niskonakładowe pisma drukowane lub powielane o zróżnicowanej periodyczności, przeznaczone w zasadzie dla pracowników pojedynczych lub kilku (najczęściej kooperujących z sobą lub sąsiadujących) zakładów tej samej lub zbliżonych branż”4. Autor uważa

Prasoznawcze” 1978, nr 1, s. 75-86; A. Świda, Prasa zakladowa w okresie przemian, „Zeszyty Prasoznawcze" 22, 1981, nr 1-2, s. 27-40; idem, Raport o prasie zakładowej. II (Próba bilansu ostatnich pięciu lat), „Zeszyty Prasoznawcze” 24, 1983, nr 2, s. 17-35; T. Biel, Z dziejów wielkopolskiej prasy zakładowej, „Kronika Wielkopolski” 1984, nr 1, s. 99-127; M. Banaszek, Polska prasa zakładowa (funkcje, charakterystyka, klasyfikacja i periodyczność), „Kwartalnik Historii Prasy Polskiej” 25, 1986, nr 2, s. 53-68; B. Pelczarski, Prasa zakładowa regionu kielecko-radomskiego, „Zeszyty Naukowe Politechniki Świętokrzyskiej. Nauki Społeczno-Ekonomiczne” 18, 1988, s. 139-148; J. Kępa, Twórcy prasy zakładowej Kielecczyzny (1945-1989), „Kieleckie Studia Bibliologiczne” 4, 1998, s. 151-167; B. Koredczuk, Pismo zakładowe „Głos Rokity” (1951-1981) jako źródło informacji o Brzegu Dolnym, [w:] Brzeg Dolny. Dzieje wybranych instytucji i zagadnień, pod red. J. Koredczuka, t. 2, Brzeg Dolny 2017, s. 249-280.

3 S. Dziki, Prasa zakładowa, [w:] Encyklopedia wiedzy o prasie, pod red. J. Maślanki, Wroclaw 1976, s. 191.

${ }^{4}$ M. Banaszek, op. cit., s. 53. 
także, że prasa ta umożliwia kontakt kierownictwa zakładu z załogą, informuje, ale i pomaga sterować postawami oraz wpływać na ich kształtowanie. Potwierdza to wypowiedź prominentnego działacza partii, sekretarza Komitetu Centralnego PZPR, dziennikarza Mieczysława Rakowskiego, który w 1950 roku pisał:

Gazetka fabryczna jest organem Komitetu Partyjnego i Rady Zakładowej danego zakładu pracy. Komitet Partyjny kieruje gazetką, czuwa nad tym, aby gazetka realizowała wskazania partii i rządu przenoszone na zakład pracy. Trzeba, by Komitet Partyjny uważał gazetkę za swój organ prasowy, aby uświadomił sobie, jak potężną pomoc otrzymuje w postaci gazetki. [...] Trzeba, aby [...] stała się [ona] przedmiotem uzasadnionej dumy Komitetu Partyjnego i całej załogi danego zakładu. [...] Zadaniem Organizacji Partyjnej jest wzbudzić wśród członków partii i bezpartyjnych duży szacunek dla gazetki, wpoić w ich świadomość fakt posiadania własnej gazetki, do której mogą i powinni stale się zwracać. [...] Prasa fabryczna - to przede wszystkie bojowy pomocnik partyjnych i związkowych organizacji na zakładzie pracy ${ }^{5}$.

Natomiast definicja gazet zakładowych przyjęta do celów statystycznych przez Bibliotekę Narodową określała je jako „periodyki dla pracowników dużych zakładów pracy informujące o życiu kulturalnym i społecznym na terenie danego zakładu" 6 .

Sylwester Dziki w cytowanym haśle encyklopedycznym, biorąc za podstawę status społeczno-prawny, wyróżnił dwie grupy prasy zakładowej: „a) reprezentujące interesy dyrekcji zakładu (grupa dominująca w krajach kapitalistycznych), b) reprezentujące linię programową związków zawodowych, organizacji politycznych i społecznych działających na terenie zakładu"7. Natomiast Banaszek wziął pod uwagę zawartość, sposób redagowania, formę edytorską, zasięg i rodzaj środowiska czytelniczego i podzielił prasę zakładową na sześć grup:

1. Biuletyny informacyjne zawierające komunikaty i zalecenia kierownictwa zakładu lub zakładowych organizacji politycznych, zawodowych, samorządowych i społecznych, a także sprawozdania z ich działalności.

2. Wąskospecjalistyczne pisma zakładowe lub wielozakładowe o charakterze fachowym, poświęcone głównie problemom racjonalizacji i wynalazczości, postępowi technicznemu i ekonomicznemu, organizacji pracy i BHP, a wydawane przez określone działy przedsiębiorstwa lub zakładowe organizacje techniczno-ekonomiczne.

3. Zakładowe wydawnictwa jednorazowe lub ciągłe, nazywane jednodniówkami.

4. Pisma zakładowe o zróżnicowanej problematyce i szacie graficznej, nazywane powszechnie gazetami, posiadające stałe, ale w różnym stopniu wyspecjalizowane redakcje.

5. Gazety międzyzakładowe lub lokalno-międzyzakładowe o charakterze informacyjno-publicystycznym, przeznaczone dla pracowników kombinatów i przedsiębiorstw wielozakładowych.

6. Prasa dla klientów, wydawana przez przedsiębiorstwa przemysłowe i usługowe ${ }^{8}$.

Autor dodaje także, że ze względu na warunki polityczne prasa ta może być jawna lub konspiracyjna.

\footnotetext{
5 M. Rakowski, Prasa fabryczna w Planie Sześcioletnim, „Prasa Polska” 1950, nr 8-9, s. 11.

6 Wstep, ,Ruch Wydawniczy w Liczbach” (dalej: „RWL”) 14, 1968, s. 7.

7 S. Dziki, op. cit., s. 192.

8 M. Banaszek, op. cit., s. 59.
} 
Funkcje prasy zakładowej wynikały przede wszystkim z oczekiwań organizacji partyjnych (Komitety Zakładowe PZPR), rad zakładowych i robotniczych, kierownictwa i samych pracowników. Cytowany Banaszek ${ }^{9}$ wyodrębnił następujące funkcje tej prasy: informacyjną, agitacyjno-propagandową, reklamową, edukacyjno-wychowawczą, popularyzatorsko-instruktażową, opiniotwórczą, inspiratorsko-organizacyjną, kontrolną, kulturotwórczą, kronikarsko-dokumentacyjną, rozrywkową.

\section{RYS HISTORYCZNO-STATYSTYCZNY PRASY ZAKŁADOWEJ W POLSCE}

Pierwsze gazety zakładowe pojawiły się w Stanach Zjednoczonych w XIX wieku, co było rezultatem powstania dużych zakładów przemysłowych oraz chęci integracji wszystkich pracowników w celu zmaksymalizowania korzyści finansowych firmy. Dynamiczny rozwój tej prasy nastąpił w okresie międzywojennym. Wtedy też powstała pierwsza gazeta zakładowa w Polsce — „Echo Chełmka” $(1934)^{10}$. Po drugiej wojnie światowej tego typu gazety pojawiły się we wszystkich krajach Europy.

Straty w ludziach, jakie dotknęły redakcje polskich czasopism, spowodowały, że w latach 1945-1949 zatrudniane były w nich często osoby przypadkowe, bez przygotowania zawodowego i — jak pisała Alina Słomkowska — „kształtowały się [redakcje] żywiołowo spośród dziennikarzy przedwojennych, związanych $\mathrm{z}$ prasą postępową, prasą konspiracyjną, z aparatu polityczno-wychowawczego Ludowego Wojska Polskiego"11. Autorka konstatowała, że w 1949 roku zakończył się proces powstawania redakcji i budowania jednolitego systemu prasy partyjnej, w której podstawową zaletą dziennikarza było jego ideologiczne zaangażowanie, a za najważniejszy materiał $\mathrm{w}$ gazecie uznano korespondencje terenowe $\mathrm{e}^{12}$. Ta nowa koncepcja pracy redakcyjnej została wykorzystana w okresie realizacji planu sześcioletniego, który przyniósł znaczący rozwój gazet zakładowych. Na ich łamach podejmowano problematykę związaną z wykonywaniem zadań, współzawodnictwem, normami, promowaniem przodowników pracy, piętnowaniem „obiboków” oraz przejawów marnotrawstwa. W opinii Ryszarda Karpowicza naczelnym celem „było przełamywanie konserwatyzmu, nieufności i umacnianie nowego ładu społeczno-politycznego, kształtowanie socjalistycznych zasad współpracy i współdziałania w zespołach pracowniczych, rozwijanie umiejętności współrządzenia, a także uczenie rzetelnej krytyki różnych przejawów zła i niego-

9 Ibidem, s. 54.

10 S. Dziki, op. cit., s. 191-192.

11 A. Słomkowska, Z badań nad dziennikarstwem Polski Ludowej, „,Rocznik Historii Czasopiśmiennictwa Polskiego" 15, 1976, z. 3, s. 320.

12 Ibidem. 
spodarności w przedsiębiorstwach"13. Z wyliczeń autora wynika, że na początku roku 1956 było w Polsce tylko 46 gazet zakładowych, które ukazywały się regularnie $^{14}$. Okres od października 1956 roku do maja 1966 roku charakteryzował się między innymi brakiem papieru, problemami poligraficznymi, co w konsekwencji odbiło się na dynamice dalszego powstawania gazet zakładowych.

Zmiany przyszły wraz z uchwałą Centralnej Rady Związków Zawodowych z 2 maja 1966 roku o „Zasadach organizacji gazet zakładowych oraz prawach i obowiązkach dziennikarza prasy zakładowej", w której stwierdzono, że są one organami samorządu robotniczego. Egzekutywy Komitetów Zakładowych PZPR — w myśl uchwały — stały się opiekunami merytorycznymi redakcji i kolegiów; te - pracując według regulaminów zatwierdzonych przez konferencję samorządu robotniczego - powinny stać się samodzielnymi działami w przedsiębiorstwie. Poprawa sytuacji gazet zakładowych następowała systematycznie od 1968 roku.

Zagadnienia pracy redakcyjnej określiła także uchwała Prezydium CRZZ z 15 stycznia 1974 roku „O zasadach organizacji i działalności gazet oraz radiowęzłów”, w myśl której oba media są organami samorządów robotniczych i działają pod ideowo-politycznym kierownictwem komitetów zakładowych PZPR. W opinii Banaszka ${ }^{15}$ istotne znaczenie miała jeszcze uchwała Rady Ministrów z 13 lipca 1973 roku w sprawie zasad zatrudnienia i wynagradzania dziennikarzy gazet i rozgłośni zakładowych - dokumenty te otwierały przed dziennikarzami prasy zakładowej możliwość pełnego członkowstwa w Stowarzyszeniu Dziennikarzy Polskich.

Być może na wzrost liczby wydawanych gazet zakładowych miała też wpływ polityka PZPR pod kierownictwem Edwarda Gierka. Partia potrzebowała pozytywnej propagandy, szerokiego udziału prasy, radia, telewizji. W październiku 1974 roku Wydział Propagandy, Prasy i Wydawnictw KC skierował do odpowiednich wydziałów w komitetach wojewódzkich wytyczne określające główne kierunki propagandy ${ }^{16}$, w czym swój udział miały także gazety zakładowe, na których łamach - tak jak w całej prasie politycznej - realizowano tak zwaną propagandę sukcesu. Wpływ na wzrost liczby wydawanych gazet zakładowych miała także poprawa zaopatrzenia $\mathrm{w}$ papier $\mathrm{w}$ drugiej połowie lat 70 . Załamanie przyniósł 13 grudnia 1981 roku i przepisy cenzury towarzyszące wprowadzeniu stanu wojennego. Zmiany w warunkach funkcjonowania przedsiębiorstw przemy-

13 R. Karpowicz, W sprawie genezy i rozwoju prasy zakładowej, „Prasa Polska” 1976, nr 7-8, s. 32.

14 Ibidem.

15 M. Banaszek, op. cit., s. 65.

16 Główne kierunki propagandy w prasie, radio i TV po XV Plenum KC PZPR, Archiwum Państwowe we Wrocławiu (dalej: APWr). KW PZPR we Wrocławiu. Wydział Propagandy. Prasa. Radio i TV. Wytyczne KC, informacje KC, oceny i informacje Wydziału Propagandy KW do Prasy, Radia i TV. 1954-1974, sygn. 965, k. 55-58. 
słowych i wprowadzenie gospodarki rynkowej po 1989 roku zmieniły sytuację prasy zakładowej.

\subsection{DYNAMIKA ROZWOJU GAZET ZAKŁADOWYCH W LATACH 1967-1992}

Prezentowane niżej dane statystyczne pozwalające ocenić stan gazet zakładowych wydawanych w Polsce zostały zaczerpnięte z oficjalnej statystyki państwa,

Tab. 1. Liczba tytułów i częstotliwość gazet zakładowych w latach 1967-1992

\begin{tabular}{|c|c|c|c|c|c|c|}
\hline Rok & Ogółem & Tygodniki & $\begin{array}{l}\text { Dwutygo- } \\
\text { dniki }\end{array}$ & $\begin{array}{c}\text { Miesięcz- } \\
\text { niki }\end{array}$ & $\begin{array}{c}\text { Dwumie- } \\
\text {-sięczniki } \\
\text { i kwar- } \\
\text {-talniki }\end{array}$ & $\begin{array}{l}\text { Nieregu- } \\
\text { larne }\end{array}$ \\
\hline 1967 & 101 & - & - & - & - & - \\
\hline 1968 & 111 & - & - & - & - & - \\
\hline 1969 & 125 & - & - & - & - & - \\
\hline 1970 & 133 & 9 & 63 & 40 & 7 & 14 \\
\hline 1971 & 145 & 10 & 65 & 39 & 5 & 26 \\
\hline 1972 & 156 & 10 & 67 & 41 & 7 & 31 \\
\hline 1973 & 169 & 10 & 75 & 47 & 1 & 36 \\
\hline 1974 & 204 & 10 & 93 & 41 & 4 & 56 \\
\hline $1975^{17}$ & 200 & 15 & 92 & 39 & - & 54 \\
\hline 1976 & 195 & 11 & 104 & 31 & - & 49 \\
\hline 1977 & 187 & 11 & 102 & 34 & - & 40 \\
\hline 1978 & 202 & 19 & 140 & 30 & - & 13 \\
\hline 1979 & 204 & 23 & 144 & 19 & - & 18 \\
\hline 1980 & 207 & 19 & 143 & 14 & - & 31 \\
\hline 1981 & 193 & 25 & 133 & 21 & - & 14 \\
\hline 1982 & 90 & 17 & 56 & 10 & - & 7 \\
\hline 1983 & 108 & 14 & 72 & 14 & - & 8 \\
\hline 1984 & 104 & 13 & 70 & 12 & - & 9 \\
\hline 1985 & 108 & 15 & 72 & 12 & - & 9 \\
\hline 1986 & 114 & 16 & 68 & 20 & - & 10 \\
\hline 1987 & 120 & 18 & 70 & 22 & - & 10 \\
\hline 1988 & 117 & 15 & 69 & 21 & $2(+1)^{18}$ & 9 \\
\hline 1989 & 114 & 16 & 66 & 21 & $1(+1)$ & 9 \\
\hline 1990 & 43 & 9 & 27 & 6 & - & 1 \\
\hline 1991 & 48 & 11 & 33 & 4 & - & - \\
\hline 1992 & 26 & 7 & 16 & 3 & - & - \\
\hline
\end{tabular}

Źródło: obliczenia własne na podstawie „RWL” 14, 1969-38, 1992.

17 Od 1975 roku nie wydawano już miesięczników i kwartalników.

18 W zestawieniu za 1988 rok podano dodatkowo dane dotyczące półroczników — ukazał się jeden w 1988 roku i jeden w następnym roku. W kolejnych latach nie były już wydawane. 
jaką jest „RWL”. Jak już wspomniano, po raz pierwszy uwzględniono je w roczniku 14 z 1968 roku $^{19}$, w którym podano też dane dotyczące roku poprzedniego.

Najwięcej tytułów (207) ukazało się w 1980 roku. Podobny poziom utrzymywał się w latach 1974-1975 i 1978-1979 (odpowiednio: 204, 200, 202, 204 tytuły). Zupełnie dobrze wyglądała też sytuacja w latach 1976-1977 i w roku 1981 (odpowiednio: 195, 187, 193 tytuły). Spadek w roku 1982 tłumaczyć należy wprowadzeniem staniu wojennego i zamknięciem wielu tytułów przez cenzurę, jednak już w kolejnych latach gazety zakładowe zaczęto przywracać. Kolejny znaczny spadek liczby tytułów widoczny jest od roku 1990. „RWL” zaprzestaje ich odnotowywania od 1992 roku. Przez pierwsze trzy lata prezentowano w zestawieniach „RWL” tylko ogólną liczbę tytułów, bez uwzględniania częstotliwości, co zaczęto robić dopiero w 1970 roku. Z kolei od 1975 roku zaprzestano podawania liczby dwumiesięczników i kwartalników.

Gazety zakładowe najczęściej ukazywały się jako dwutygodniki — najliczniej w latach 1978-1981. Równie często wydawano je jako miesięczniki, lecz tu tendencja spadkowa zaczęła być widoczna od 1979 roku. Liczba nieregularnie ukazujących się gazet zakładowych w latach 1974-1977 była dość znaczna, ale z czasem zaczęły one zanikać, aż do ustabilizowania się na poziomie 9-10 w latach 80. XX wieku. Na krótko powróciły dwumiesięczniki i kwartalniki, a nawet — w latach 1988 i 1989 — półroczniki.

\subsection{GAZETY ZAKŁADOWE WEDŁUG GEOGRAFII WYDAWNICZEJ W LATACH 1967-1992}

Gazety zakładowe najliczniej wydawane były na terenach uprzemysłowionych. Bardzo dobra sytuacja panowała przez cały badany okres w województwie katowickim, w którym już w 1968 roku ukazywało się 10 tytułów. Mniej więcej ten sam poziom utrzymywały województwo opolskie i od 1971 roku także bydgoskie. Do 1974 roku stabilna była sytuacja w województwach: kieleckim, krakowskim, warszawskim, wrocławskim i zielonogórskim — wszędzie liczba tytułów zakładowych oscylowała między 7 a 9. Podobnie, choć na nieco niższym poziomie, było w województwach: lubelskim i rzeszowskim (6-7 tytułów), łódzkim, gdańskim i olsztyńskim (2-3 tytułów). Spośród dużych miast - Krakowa, Łodzi, Poznania, Warszawy i Wrocławia ${ }^{20}$ — zdecydowanie najwięcej gazet zakładowych ukazywało się w mieście stołecznym, największym, z najlepiej rozwiniętymi zakładami przemysłowymi. Tu średnio wydawano 31 tytułów.

19 Wprowadzając do „RWL” dane dotyczące gazet zakładowych, zaznaczono, że „Mogą być jednak wątpliwości, co do kompletności tego materiału, tym samym dokładności podanego zestawienia". Z takim samym zastrzeżeniem dane te prezentowane są tutaj.

${ }^{20}$ W latach 1968-1974 poza danymi dla województw w „RWL” podawano osobno liczbę gazet zakładowych wydanych w Krakowie, Łodzi, Poznaniu, Warszawie i Wrocławiu. W tabeli zapisano je w nawiasie okrągłym. 
Tab. 2. Liczba tytułów gazet zakładowych w latach 1968-1974 (według podziału administracyjnego z 1957 roku)

\begin{tabular}{|l|c|c|c|c|c|c|c|}
\hline \multicolumn{1}{|c|}{ Województwo } & 1968 & 1969 & 1970 & 1971 & 1972 & 1973 & 1974 \\
\hline białostockie & - & - & 1 & 1 & 1 & 1 & 1 \\
\hline bydgoskie & 4 & 6 & 8 & 11 & 12 & 14 & 16 \\
\hline gdańskie & 1 & 2 & 3 & 2 & 2 & 2 & 2 \\
\hline katowickie & 10 & 10 & 10 & 10 & 14 & 24 & 30 \\
\hline kieleckie & 7 & 8 & 8 & 8 & 8 & 11 & 10 \\
\hline koszalińskie & - & - & 1 & 1 & 1 & 2 & 1 \\
\hline $\begin{array}{l}\text { krakowskie } \\
\text { (z Krakowem) }\end{array}$ & $7(+1)$ & $7(+4)$ & $7(+4)$ & $8(+3)$ & $8(+2)$ & $7(+1)$ & $9(+5)$ \\
\hline lubelskie & 6 & 6 & 6 & 7 & 6 & 5 & 6 \\
\hline $\begin{array}{l}\text { lódzkie } \\
\text { (z Łodzią) }\end{array}$ & 3 & 2 & 2 & $2(+1)$ & $3(+2)$ & $2(+2)$ & $3(+4)$ \\
\hline olsztyńskie & 1 & 1 & 1 & 2 & 2 & 2 & 3 \\
\hline opolskie & 9 & 10 & 9 & 10 & 10 & 12 & 16 \\
\hline $\begin{array}{l}\text { poznańskie } \\
\text { (z Poznaniem) }\end{array}$ & $1(+7)$ & $1(+6)$ & $1(+6)$ & $1(+7)$ & $3(+8)$ & $7(+8)$ & $7(+9)$ \\
\hline rzeszowskie & 4 & 4 & 5 & 6 & 6 & 6 & 9 \\
\hline szczecińskie & 4 & 4 & 5 & 5 & 8 & 6 & 7 \\
\hline $\begin{array}{l}\text { warszawskie } \\
\text { (z Warszawą) }\end{array}$ & $5(+27)$ & $6(+31)$ & $7(+32)$ & $8(+31)$ & $7(+31)$ & $6(+27)$ & $6(+31)$ \\
\hline $\begin{array}{l}\text { wrocławskie } \\
(z \text { Wrocławiem) }\end{array}$ & $5(+5)$ & $6(+6)$ & $6(+5)$ & $8(+6)$ & $7(+7)$ & $8(+7)$ & $11(+9)$ \\
\hline zielonogórskie & 4 & 5 & 6 & 7 & 8 & 9 & 9 \\
\hline RAZEM & 111 & 125 & 133 & 145 & 156 & 169 & 204 \\
\hline
\end{tabular}

Źródło: obliczenia własne na podstawie „RWL” 14, 1969-19, 1974.

Najbardziej dynamiczny wzrost — z 6 do 33 tytułów, czyli ponad pięciokrotny — nastąpił w 1975 roku w województwie warszawskim. Liczba ta utrzymała się do 1981 roku, później zmalała do 27 . W tym samym okresie nastąpił też wzrost w województwie poznańskim - z 7 do 12 tytułów. W całym badanym okresie dobra była sytuacja w województwie katowickim - tam wzrost do 30 nastąpił w 1974 roku i trwał do 1981 roku, po czym liczba tytułów wróciła do początkowych 10 . Na stałym poziomie 9-10 tytułów utrzymywały się gazety zakładowe w województwie opolskim. Były też województwa, w których przez cały badany okres wydawano pojedyncze tytuły: na przykład chełmskie (z kilkuletnią przerwą), elbląskie, gorzowskie (początkowo 2-3, od 1982 tylko jeden), słupskie (z przerwami). 


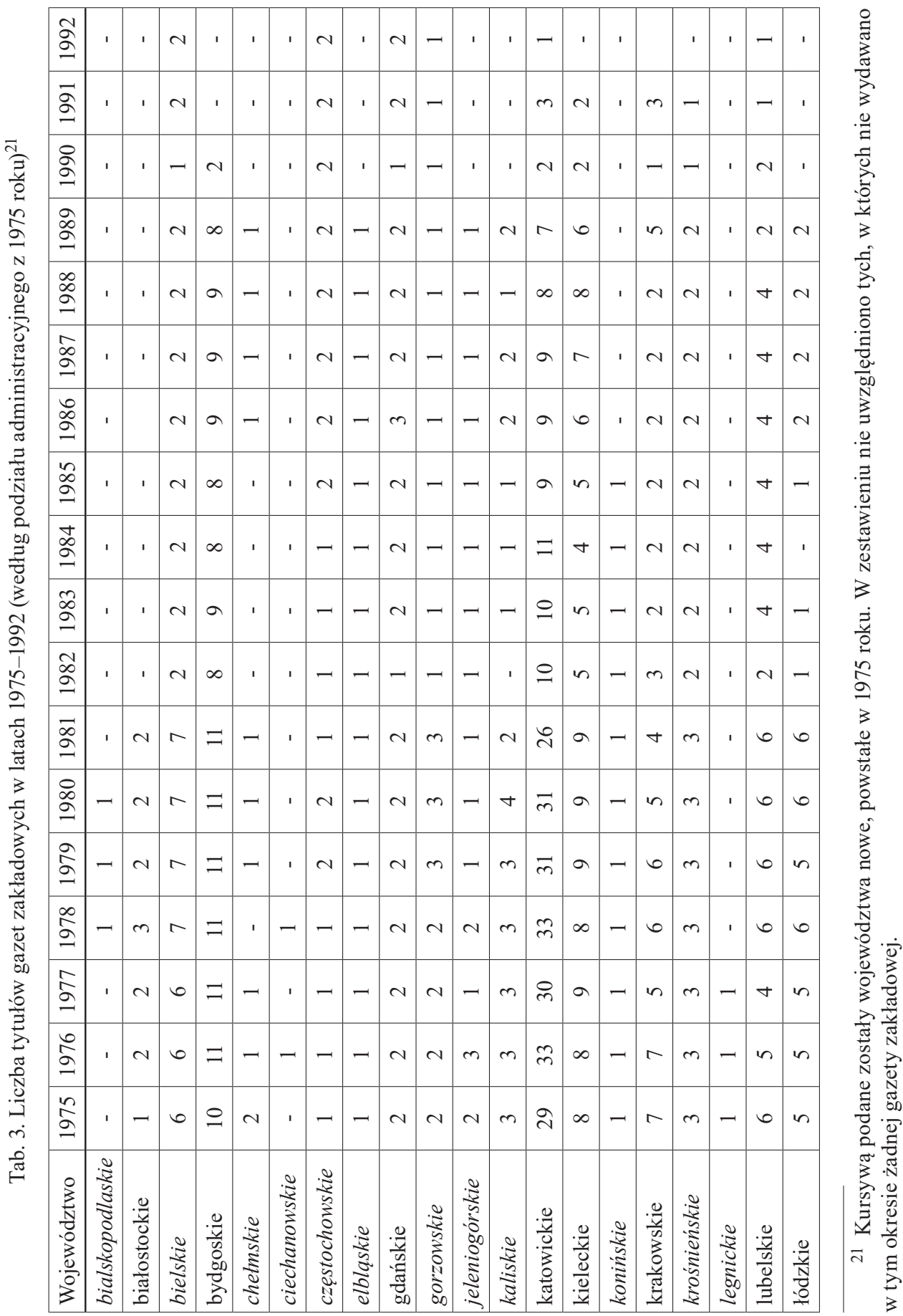




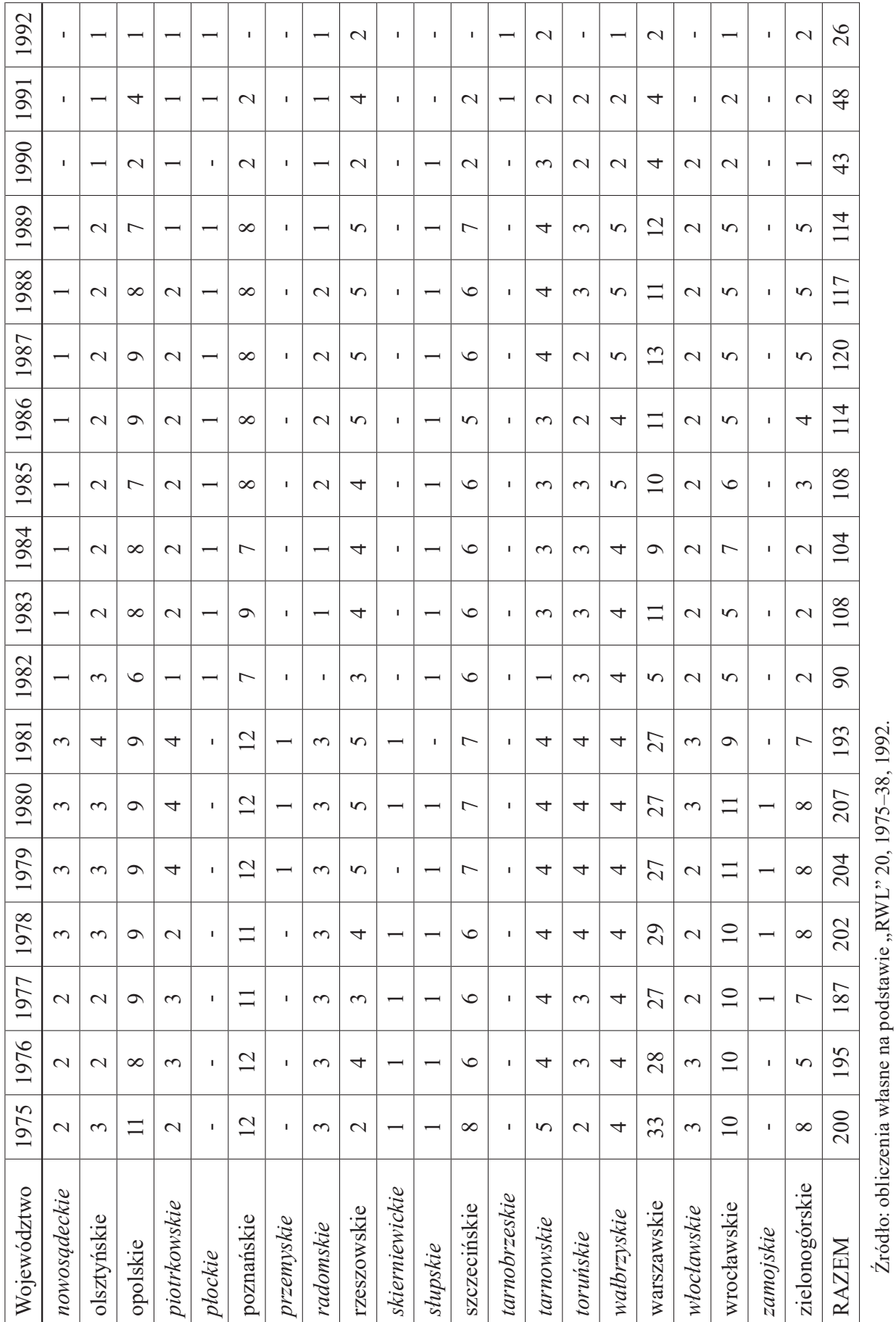


Po zawieszeniu wydawania gazet i czasopism w związku z wprowadzeniem stanu wojennego ich częściowa reaktywacja nastąpiła w 1982 roku, choć spadek liczby tytułów był znaczny. Po roku wznowiono ich wydawanie w województwach: gdańskim, piotrkowskim i tarnowskim, a po kilkuletniej przerwie w województwach: gorzowskim, kaliskim, łódzkim, nowosądeckim, radomskim; nie wznowiono już ich wydawania w województwie białostockim. Zmiany polityczno-gospodarcze po 1989 roku spowodowały, że wiele tytułów zniknęło, część zmieniono, rozszerzając ich zasięg oddziaływania, często przekształcając je w bliską zadaniowo prasę lokalną lub branżową i fachową. Spojrzenie na całą tabelę uzmysławia, że na ogół mamy do czynienia z utrzymywaniem się stałej tendencji w poszczególnych województwach.

2. POLITYCZNE, IDEOLOGICZNE I ZAWODOWE UWARUNKOWANIA FUNKCJONOWANIA I ROZWOJU PRASY ZAKŁADOWEJ NA DOLNYM ŚLACSKU (W ŚWIETLE DOKUMENTACJI ARCHIWALNEJ KW PZPR WE WROCŁAWIU)

W zespole archiwaliów wytworzonych w KW PZPR we Wrocławiu znajduje się kilka teczek dokumentów dotyczących działalności środków masowego komunikowania, w tym gazet zakładowych. Zawarte w nich informacje odnoszą się do ogólnych założeń funkcjonowania gazet zakładowych, wymogów stawianych dziennikarzom oraz planów pracy poszczególnych redakcji.

Interesującym dokumentem z 22 listopada 1969 roku jest Informacja o stanie realizacji Wniosków Komisji Ideologiczno-Propagandowej Komitetu Wojewódzkiego PZPR w sprawie podniesienia poziomu oraz poprawy warunków pracy gazet zakładowych $w$ województwie wrocławskim ${ }^{22}$. Komisja uznała, że mają one na Dolnym Śląsku ${ }^{23}$ istotne znaczenie, które przejawia się przede wszystkim w kształtowaniu socjalistycznych stosunków międzyludzkich, ,uruchamianiu inicjatyw i aktywności produkcyjnej kolektywów pracowniczych, oddziaływania na postawę ideową załóg", ale też dopatrzyła się w pracy zespołów redakcyjnych braków i niedomagań. Za podstawowe trudności uznała:

1. braki w przydziale papieru, uniemożliwiające zwiększenie formatu, nakładów i częstotliwości wydawania gazet, co jest wynikiem obowiązującego, sztywnego systemu przydziału limitów;

2. nieterminowość druku gazet, która niweczy skuteczność ich oddziaływania;

22 Informacja o stanie realizacji Wniosków Komisji Ideologiczno-Propagandowej Komitetu Wojewódzkiego PZPR w sprawie podniesienia poziomu oraz poprawy warunków pracy gazet zakładowych w województwie wrocławskim. APWr. KW PZPR we Wrocławiu. Wydział Propagandy, Oświaty i Kultury KW PZPR, [Plany pracy, analizy i korespondencje dot. działalności środków masowego przekazu] 1971, sygn. 970, k. 42-44.

23 Ich liczbę oszacowano tu na 14 tytułów. Według zestawienia statystycznego w tabeli 2 było ich 12 . 
3. trudności kadrowe (brak pracowników, etatów, uregulowanych stosunków służbowych) i nieprzestrzeganie przez zakłady obowiązujących przepisów i regulaminów.

W związku z tym Komisja skierowała wnioski do:

- powiatowych i dzielnicowych instancji, a także organizacji partyjnych, nakładając na nie obowiązek okresowej oceny poziomu gazet zakładowych (treści i formy) oraz kadry dziennikarskiej;

- Wojewódzkiej Komisji Związków Zawodowych (WKZZ) o przeprowadzenie społecznej kontroli warunków organizacyjno-technicznych pracy wszystkich redakcji gazet zakładowych.

Celem dalszego doskonalenia pracy kadry dziennikarskiej w redakcjach gazet zakładowych Wojewódzki Klub Redaktorów Gazet Zakładowych miał prowadzić systematyczne narady szkoleniowe o charakterze seminaryjnym. WKZZ powinna wspomagać je organizacyjnie i finansowo. Szczególna uwaga w szkoleniu redaktorów naczelnych należna była problematyce ideologicznej oraz ekonomicznej. Wykładowcy angażowani byli z zespołu lektorów KW PZPR, Stowarzyszenia Dziennikarzy Polskich i Uniwersytetu Wrocławskiego. Pozytywnie oceniono systematyczne powiększanie się grona współpracowników gazet. W dokumencie Aktualne problemy prasy zakładowej w województwie wrocławskim ${ }^{24}$ (z listopada 1976 roku) przeprowadzono analizę wspomnianej już uchwały Prezydium Centralnej Rady Związków Zawodowych (CRZZ) z 15 stycznia 1974 roku „O zasadach organizacji i działalności gazet oraz radiowęzłów". Wynikało z niej, że redaktor naczelny, wraz z całą redakcją, powinien być podporządkowany bezpośrednio dyrektorowi naczelnemu.

Formalnym wyrazem dobrze zorganizowanych kontaktów zakładowej organizacji partyjnej z gazetą powinno być objęcie funkcji przewodniczącego kolegium redakcyjnego przez aktualnego sekretarza komitetu zakładowego PZPR. [...] Kontrolna funkcja komitetów zakładowych powinna się przejawiać m.in. w dokonywaniu okresowych ocen i analiz działalności redakcji i kolegium redakcyjnego.

\section{I dalej:}

Sytuacja kadrowa redakcji gazet zakładowych jest w naszym województwie na ogół korzystna, przeciętnie każda zatrudnia 2 etatowych dziennikarzy oraz redaktora technicznego na połowie etatu. [...] Z 10 redaktorów naczelnych 7 to członkowie PZPR -1 należy do ZSMP $25-2$ osoby są bezpartyjne. Jedynie w 1 przypadku staż pracy w dziennikarstwie redaktora naczelnego wynosi 1 rok, pozostali pracują w zawodzie ponad 5 lat, a kilku ponad 10. Trzy osoby uzupełniają wykształcenie specjalistyczne, jedna ma niepełne wyższe, a sześciu redaktorów naczelnych posiada

24 Aktualne problemy prasy zakładowej w województwie wrocławskim. APWr. KW PZPR we Wrocławiu. Pion Ideologiczny KW PZPR. Wydział Ideologiczny KW PZPR, Informacje, wnioski, uwagi o pracy radiowęzłów zakładowych, plany pracy rozgłośni zakładowych, oceny pracy dziennikarzy [1977-1980], sygn. 2754, k. 8-11.

25 Związek Socjalistycznej Młodzieży Polskiej. 
pełne wyższe wykształcenie. Ponadto pozostali pracownicy redakcji również posiadają wyższe wykształcenie lub je aktualnie uzupełniają [...].

Więcej informacji na temat dziennikarzy pracujących w redakcjach gazet zakładowych dostarcza Informacja dotyczaca oceny dziennikarzy gazet zakłado$w_{y c h}{ }^{26}$ z 20 maja 1978 roku. Dwa zespoły, złożone z funkcjonariuszy partyjnych oraz redaktorów naczelnych „Słowa Polskiego" i „Gazety Robotniczej”, oceniły 21 dziennikarzy z 24 zatrudnionych w 10 gazetach zakładowych województwa wrocławskiego. W tej grupie 11 osób było członkami partii, 1 - kandydatem i 9 - bezpartyjnych. Wyższe wykształcenie miało 18 osób (w tym 3 dziennikarskie), 3 - średnie. W większości byli to ludzie młodzi: 14 osób w wieku 30-40 lat, 3 - powyżej 40 lat. Oceniani dziennikarze jako specjalizację tematyczną zadeklarowali: gospodarczą — 15 osób, partyjną — 10, społeczną - 10, kulturalną -2 , sport i turystykę -2 , transport -2 , młodzieżową -1 , kobiecą - 1 . Zauważono także, że przeprowadzone $\mathrm{z}$ dziennikarzami rozmowy były

potwierdzeniem ciągle rosnącego znaczenia gazet zakładowych, a także uznaniem ich za pełnoprawną część systemu prasy w PRL. [...] Zespół jednomyślnie stwierdził, że najlepsze warunki dla działalności publicystyczno-informacyjnej posiadają gazety w tych zakładach, gdzie komitety zakładowe prawidłowo sprawują funkcję kontrolno-inspiracyjną.

Wnioskowano, aby w dalszej działalności publicystyczno-informacyjnej dziennikarze prasy zakładowej częściej zwracali uwagę na bezpośrednio agitacyjny charakter swoich materiałów, ponieważ nadal ,przeważa pozbawiony refleksji opis faktów bez głębszej analizy ich przyczyn". Ponadto stwierdzono konieczność powołania sekretariatów redakcji we wszystkich gazetach zakładowych, włączenia dziennikarzy do jednolitego systemu szkolenia i doskonalenia kadr dziennikarskich (szkolenie warsztatowe i polityczne), uporządkowania szaty graficznej, uregulowania kontaktów gazet zakładowych z drukarniami, poprawy warunków lokalowych redakcji, zlikwidowania nieuzasadnionych różnic płacowych pomiędzy redakcjami oraz dużych różnic w obsadzie kadrowej. W analizowanych dokumentach często powracała sprawa pozyskiwania korespondentów robotniczych, poszerzenia składu kolegiów o przedstawicieli wszystkich działów produkcyjnych. Ocenę swojej działalności — jak czytamy w dokumencie — dziennikarze przyjęli dobrze.

W analizowanym okresie we Wrocławiu ukazywało się osiem gazet zakładowych: „Pafawag” (1946-1990), „Ku Nowemu” (1954-1990), „Żeglarz Odrzański” (1954-1981), „Życie Załogi” (1956-1981), „Nasze Problemy” (1969-1990), „Intermoda” (1972-1981), „Elwro” (1973-1981), „Polar” (1976-1981). Po jednej wydawano w zakładach w Brzegu Dolnym (,Głos Rokity”, 1954-1981) i w Jelczu-

${ }^{26}$ Informacja dotyczaca oceny dziennikarzy gazet zakładowych. APWr. KW PZPR we Wrocławiu. Pion Ideologiczny KW PZPR. Wydział Ideologiczny KW PZPR, Informacje, wnioski, uwagi o pracy radiowęzłów zakładowych, plany pracy rozgłośni zakładowych, oceny pracy dziennikarzy [1977-1980], sygn. 2754, k. 40-42, 45. 
-Laskowicach („Głos Jelcza”, 1962-2001). Zostaną one omówione w porządku chronologicznym.

\section{3. „PAFAWAG. DWUTYGODNIK PRACOWNIKÓW P.F.W.” (1946-1990) ${ }^{27}$}

Pierwszy numer dwutygodnika „Pafawag”28 ukazał się 10 kwietnia 1946 roku i od tej pory wychodził 10 i 25 każdego miesiąca. Kolejne winiety tytułowe w bardzo wyrazisty sposób ilustrowały zmiany w profilu produkcji, a także aktualną sytuację polityczną. Pierwsza przedstawiała dwie węglarki jadące w przeciwnych kierunkach. Z czasem zastąpił je pociąg osobowy, którego pierwszy wagon wjeżdżał w cyfrę 6 - symbol planu sześcioletniego. Kolejna zmiana przyniosła wizerunek nowoczesnego pociągu wyjeżdżającego z bram fabryki, nad którą góruje czerwona, radziecka gwiazda. W 1956 roku rysunek fabryki zastąpiono symbolami miasta - Halą Ludową (obecnie Stulecia) i Iglicą. W winiecie tytułowej pojawiały się też wizerunkowe odpowiedniki kolejnych odznaczeń przyznawanych fabryce: w 1966 roku odznaka Związku Zawodowego Metalowców, w 1972 roku — „Budowniczego Wrocławia”. Charakterystyczne dla „Pafawagu” były hasła widniejące nad tytułem, a mianowicie: „Niech żyje Armia Radziecka Wyzwolicielka Polski - Armia Pokoju”; ,Jednolite i demokratyczne Niemcy — warunkiem zapewnienia pokoju w Europie”; „Współzawodnictwo i racjonalizatorstwo - to niezwyciężona broń światowego pokoju". W 1975 roku pojawiło się też hasło będące zawołaniem komunistów „Proletariusze wszystkich krajów łączcie się!”. Wszystkie zniknęły w 1980 roku. Widniejący w winiecie podtytuł również ulegał zmianom, odzwierciedlając aktualną sytuację w fabryce ${ }^{29}$, co było zjawiskiem typowym także dla innych gazet zakładowych.

27 Fabryka wagonów, lokomotyw oraz maszyn, powstała w 1839 roku jako Linke-Hofmann-Werke AG. W 1945 roku zakład został przejęty przez grupę operacyjną. Funkcjonował od maja do lipca jako Państwowa Fabryka Wagonów we Wrocławiu. W końcu 1945 roku załoga liczyła 1400 osób. Początkowo produkowano węglarki, potem także platformy, wagony osobowe. Po odbudowie i modernizacji fabryka stała się największym zakładem przemysłowym Wrocławia, liczącym 6000 robotników, i traktowana była jako sztandarowe przedsiębiorstwo socjalistyczne. W latach 60. XX wieku produkowano tu lokomotywy elektryczne oraz różnego rodzaju tabor kolejowy dla ruchu towarowego i pasażerskiego. Od 2000 roku jest własnością kanadyjskiej firmy Bombardier. Pafawag, [hasło w:] Encyklopedia Wrocławia, pod red. J. Harasimowicza, Wrocław 2006 (dalej: EW), s. 641.

28 „Pafawag” w zasobie Biblioteki Uniwersytetu Wrocławskiego (dalej: BUWr) pod sygn. 31136 IV GŚŁ, pełny zasób: 1945-1990.

29 W 1951 roku dodano w podtytule informację, iż „Pafawag” jest organem Komitetu Fabrycznego PZPR, Zarządu Zakładowego ZMP i Rady Zakładowej. W 1952 roku dodano jeszcze słowo [i] Dyrekcji. W 1959 roku — Organ Konferencji Samorządu Robotniczego. 
Gazeta miała mały format $21 \times 31 \mathrm{~cm}$, który wielokrotnie był przekształcany ${ }^{30}$. Stosowano układ sześcioszpaltowy, o objętości czterech stron, a w numerach świątecznych — ośmiu. Informacje o nakładzie pojawiły się po raz pierwszy w stopce redakcyjnej w 1948 roku, gdzie podano liczbę 4700 egzemplarzy. Od 1952 roku nakład był właściwie stały i oscylował pomiędzy 5000 a 6000 egzemplarzy. W 1981 roku spadł do 2000, a w okresie stanu wojennego - do 1500 egzemplarzy i na tym poziomie pozostał do końca. W 1946 roku gazeta była drukowana w Drukarni Spółdzielni Wydawniczej „Wiedza” przy ul. Wierzbowej 12, a następnie w Zakładach Graficznych RSW „Prasa”, podobnie jak wszystkie pozostałe gazety zakładowe.

Skład redakcji po raz pierwszy został podany w numerze 7 z 1948 roku, w którym wymieniono nazwisko Tadeusza Oryńskiego jako redaktora naczelnego. Kolejny raz osoby pracujące nad „Pafawagiem” zostały przedstawione czytelnikom w 1956 roku, w numerze 16. Byli to: Mirosław Dziewiecki, Bronisław Jeż, Roman Karpiński (redaktor), Józef Kowalski, Stanisław Kulpa, Zdzisław Latach, Leszek Milewski, Piotr Wiznek, Julian Cierpis. Od 1957 roku redakcją kierował Henryk Dzwilewski. Od numeru 1 z 1959 roku redaktorem naczelnym był Leszek Milewski, od numeru 7 - Halina Widomska. W 1975 roku funkcję tę przejął J. Skałecki, a w latach 1976-1989 „Pafawag” prowadził Stanisław Wolniewicz.

Pierwsze numery czasopisma z lat 1946-1948 swoim formatem i ukształtowaniem treści bardzo przypominają międzywojenne jednodniówki. Nie brak w nich koloru i humoru, na przykład w rubryce Ob. Tenderek ma głos (w 1947 roku tytuł rubryki zamieniono na $o b$. Weglarek ma głos), w której różne problemy fabryki przedstawiono $\mathrm{w}$ formie rysunku satyrycznego. Zamieszczane były też nieobecne w żadnej innej gazecie — reklamy, na przykład Zakładu Masarskiego Kazimierza Zielińskiego czy Zakładu Fotograficznego „Foto-Tęcza” z Wrocławia.

Informacje ogólnopolskie zajmowały sporo miejsca, ale cały czas obecna była tematyka samej fabryki, jej kolejnych sukcesów produkcyjnych i nowych zamówień. Publikowano artykuły poświęcone 3-letniemu planowi odbudowy, wywiady, felietony o tematyce fabrycznej, informacje sportowe, odpowiedzi na listy, kronikę fabryczną, która zawierała wiadomości kryminalne (kradzieże, włamania, poczynania straży fabrycznej). Była też „Kolumna Honoru”, w której przedstawiano najlepszych pracowników, były życzenia imieninowe dla solenizantów. Nie zapominano o pracującej młodzieży, poświęcając jej „Mały dodatek dla wszystkich młodych — Pafawag" (1946, nr 7).

Od kongresu zjednoczeniowego PZPR, któremu ze zrozumiałych względów poświęcono w 1948 roku wiele uwagi, charakter gazety znacznie się zmienił: po-

30 W 1950 roku „Pafawag” rozrósł się do formatu $30,5 \times 42,5 \mathrm{~cm}$, po dwóch latach przywrócono go do małych rozmiarów, ale w 1956 roku gazeta ponownie zwiększyła swój format $(35 \times 49,5)$. Ostatecznie od 1972 roku wyglądała tak, jak centralne dzienniki polityczne $(37 \times 52,5 \mathrm{~cm})$. 
jawiły się teksty na temat dobrobytu, którego gwarantem był socjalizm, prezentowano sukcesy partii, doniesienia z konferencji sprawozdawczo-wyborczych, wyniki współzawodnictwa, podejmowane czyny przedkongresowe. Przedstawiano sylwetki Lenina, Stalina i Bieruta. Pisano o udziale fabryki w gospodarce kraju, o pracownikach i ich dzieciach, przedstawiano propozycje biblioteki zakładowej, relacjonowano wycieczki, wczasy pracownicze i kolonie letnie. $Z$ biegiem lat pojawiły się: „Dodatek techniczny” (1963), „Kolumna Młodych” (1974) — obecna także we wszystkich innych gazetach zakładowych, cykl „Sojusz Świata Pracy z Kulturą i Sztuką", rubryka Niezależnego Samorządnego Związku Zawodowego (NSZZ) Solidarność (od 1980). Odnotować też trzeba informacje na temat Panoramy Racławickiej, relacje po zamachu na Jana Pawła II. Każdego roku gościła w „Pafawagu” „Szopka Noworoczna”, czyli satyryczny rysunek, którego bohaterami były najważniejsze, najbardziej charakterystyczne osoby z zakładu pracy, przede wszystkim kierownictwo, przedstawiciele Podstawowej Organizacji Partyjnej, Komitetu Zakładowego PZPR, Rady Zakładowej.

\section{4. „KU NOWEMU. ORGAN KOMITETU FABRYCZNEGO PZPR, RADY ZAKŁADOWEJ, ZMP I DYREKCJI M-5”(1954-1990)}

Wydając pierwszy numer gazety ${ }^{31}$ zakładowej „Ku Nowemu” — czytamy w artykule redakcyjnym z marca 1954 roku — zdajemy sobie w pełni sprawę z braków tej pierwszej gazetki, zarówno jeśli chodzi o treść, jak i o szatę graficzną. [...] redakcja zwraca się do Was, do wszystkich pracowników M-5 [Wydział Mechaniczny] ${ }^{32}$, do załóg wszystkich wydziałów, do pracowników SIMP-u [Stowarzyszenie Inżynierów i Techników Mechaników Polskich] i SEP-u [Stowarzyszenie Elektryków Polskich], do inżynierów i techników, o jak najszerszą współpracę w wydawaniu gazetki [...]"33.

Rzeczywiście, numer ten nie robił dobrego wrażenia: mały format, cztery szpalty, kilka zdjęć, papier gazetowy, kolorowy tylko tytuł i rysunek przedstawiający symbol zakładów.

31 W BUWr, pod sygn. 29030 IV GŚŁ, pełny zasób: 1954-1990.

32 Zakład Dolmel powstał na bazie działających tu wcześniej Zakładów Linke-Hoffmann Wydział Turbin oraz Zakładów „Famo”, w czasie drugiej wojny światowej produkował na potrzeby przemysłu zbrojeniowego. W 1947 roku po odgruzowaniu zniszczonego w 80\% zakładu powstał Dolmel, nazwa pierwotna - Fabryka Wielkich Maszyn Elektrycznych, późniejsza — Dolnośląskie Zakłady Wytwórcze Maszyn Elektrycznych imienia Feliksa Dzierżyńskiego. Fabryka stała się znaczącym producentem urządzeń elektroenergetycznych dostarczających maszyny i urządzenia dla takich zakładów, jak Huta Katowice, KGHM Lubin-Polkowice, cementownia Górażdże i wielu innych. Po przemianach ustrojowych w Polsce w latach 90. XX wieku stał się on własnością szwajcarsko-szwedzkiego koncernu Asea Brown Boveri (ABB). Podzielono go na nowe podmioty gospodarcze. Dolmel, [hasło w:] EW, s. 144.

33 Od Redakcji, „Ku Nowemu” 1954, nr 1, s. 1. 


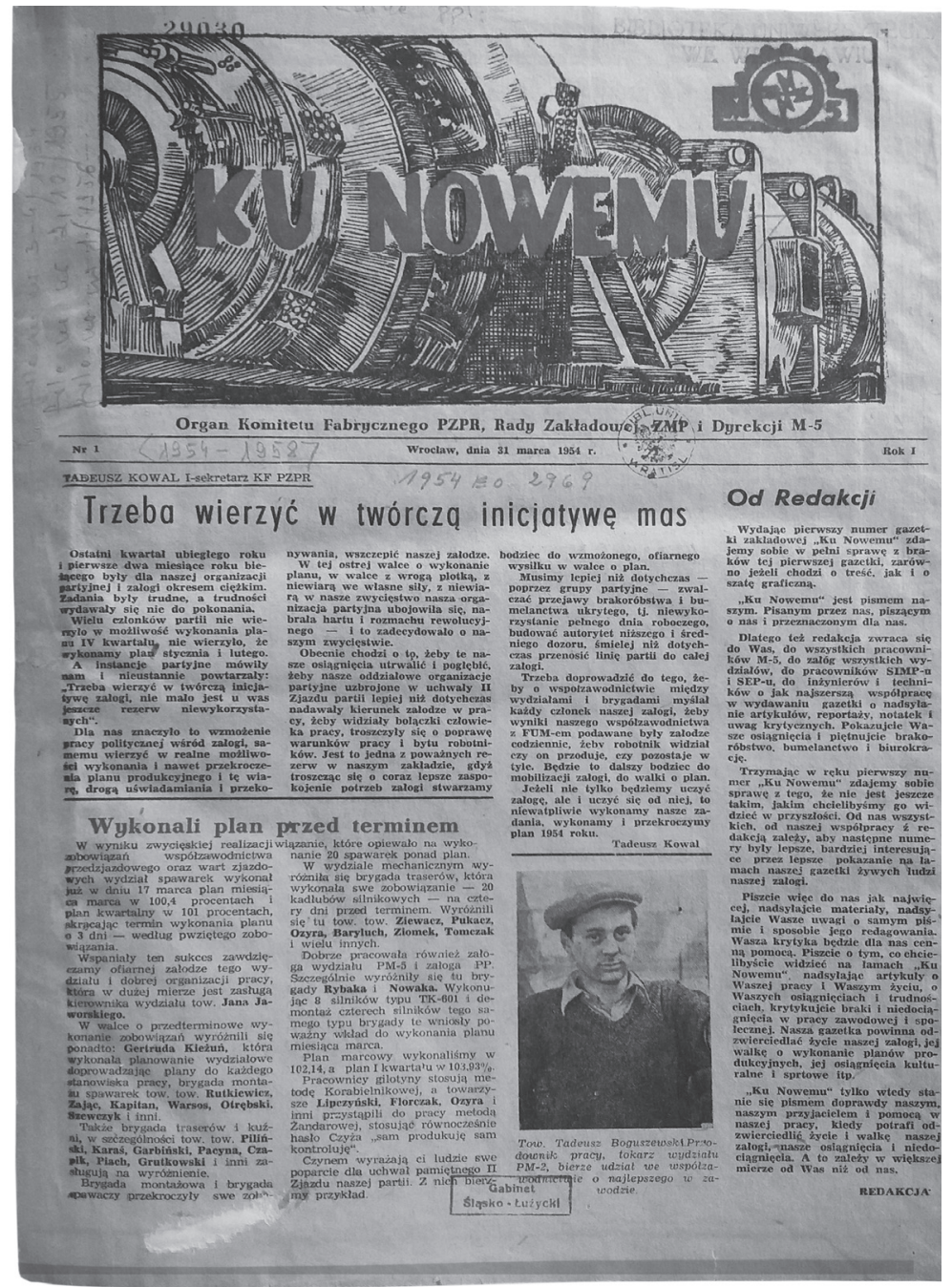

Il. 1. Strona tytułowa czasopisma zakładowego „Ku Nowemu” (właścicielem oryginału jest Biblioteka Uniwersytecka we Wrocławiu)

Szybko, bo już w styczniu następnego roku, gazeta dostała nowy tytuł: ,Turbogigant”, z podtytułem „Organ Pracowników D/Śl [Dolnośląskich] Zakł[adów] Masz[yn] Elektr[ycznych] M-5 im. F. Dzierżyńskiego" i nową winietą przedstawiającą zespół prądotwórczy - tytułowy turbogenerator - i symboliczne koło zębate. Na kolejną zmianę nie kazano czekać długo — w 1956 roku gazeta ukazała się jako „Echo M-5. Organ Załogi DZWME [Dolnośląskich Zakładów Wytwórczych Maszyn Elektrycznych] M-5”; od 1961 roku z podtytułem „Organ Samorządu Robotniczego". 


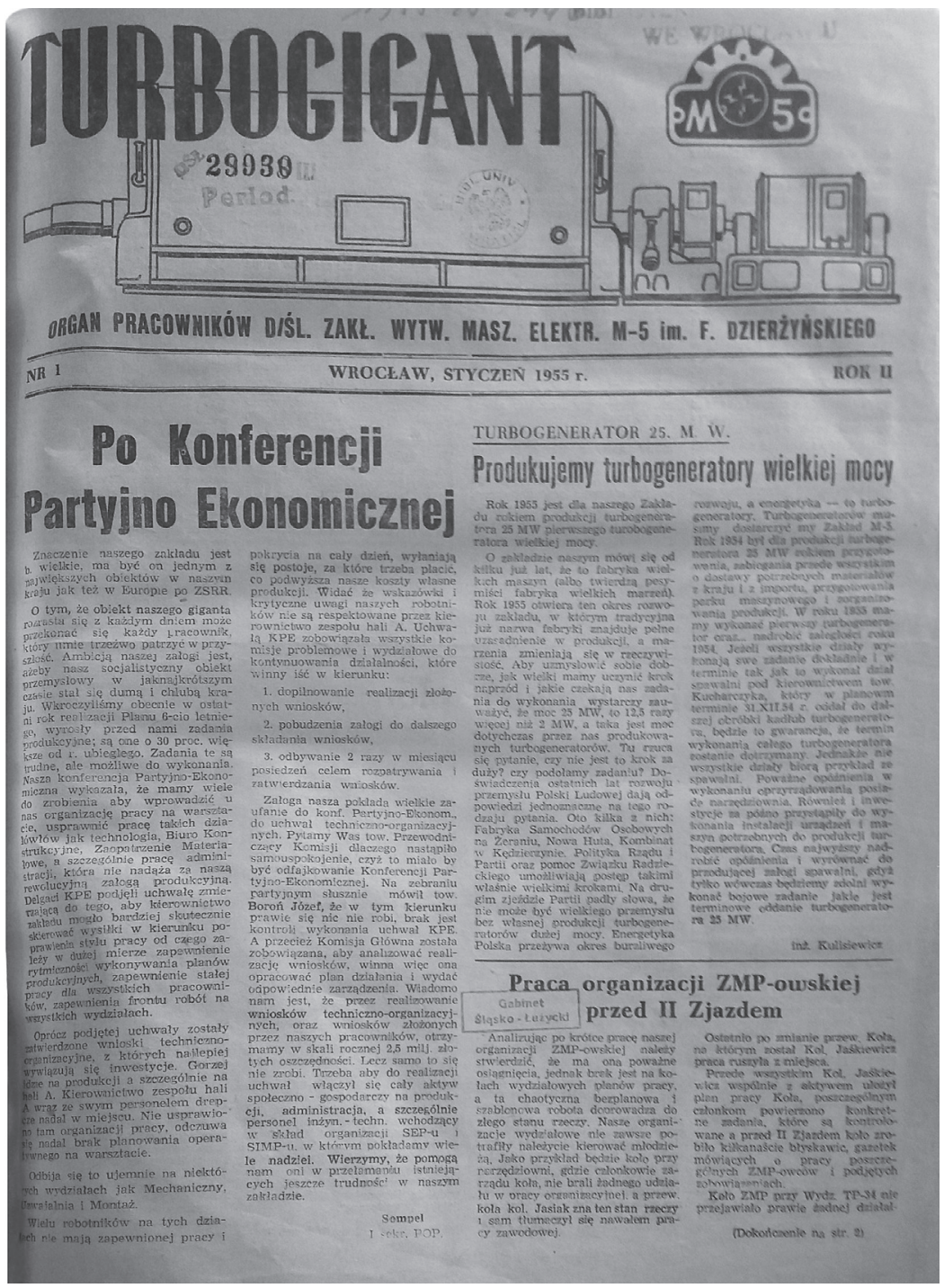

I1. 2. Strona tytułowa czasopisma zakładowego „Turbogigant” (właścicielem oryginału jest Biblioteka Uniwersytecka we Wrocławiu)

Początkowy format 25,5 × 34,5 cm utrzymał się przez dłuższy czas. Bywało, że na specjalne okazje, na przykład 22 lipca, gazetę drukowano w formacie większym $(35 \times 51 \mathrm{~cm})$, który stał się ,codziennym” pod koniec 1959 roku. Gazeta liczyła 4 strony, a numery świąteczne - 8 stron. Nakład zmieniał się — od początkowych 1,5 tys. egzemplarzy, przez 2 tys. w 1958 roku, 2,5 tys. w 1959 roku, do końcowych 1,5 tys. egzemplarzy. 
Tematy na pierwszej stronie gazety nie odbiegały od innych i dotyczyły PZPR, Związku Młodzieży Polskiej (ZMP) i innych organizacji, planu produkcji i jego wykonania, piętnowano bumelanctwo. Ostatnia strona przeznaczona była na humor, sport, wiersze, informacje kulturalne, między innymi o bibliotece zakładowej. Skład kolegium redakcyjnego podano w 1959 roku. Byli to: Wanda Agacka (redaktor naczelna), Henryk Jędrzejczak, Jan Jędrzejowski, Franciszek Kucharczyk, Mieczysław Palimąka, Stefan Piasecki, Alfred Rosiński. Podsumowując pracę zespołu w 1964 roku, pisano: „były numery słabiutkie, dobre i rozchwytywane. Tych ostatnich najwięcej w marzeniach kolegium"34.

Numer 6 z 1965 roku przyniósł zmianę tytułu na „Głos Dolmelu”, co było wynikiem przekształceń w fabryce, a w 1969 roku zmieniono podtytuł — gazeta stała się organem KRS (Komitetu Samorządu Robotniczego). Pismem Załogi DZWME gazeta była nominalnie od 1984 roku. Zmian w grafice tytułowej dokonywano w roku 1972, 1975 i 1987, kiedy ostatecznie z zadowoleniem pisano:

Nareszcie stało się - mamy nową szatę graficzną gazety. Odtąd fabryczne pismo będzie ukazywało się z nową winietą czołową, z winietkami tematycznymi mającymi wspólne elementy graficzne. Za ich sprawą oblicze gazety uzyskuje właściwy sobie charakter. Całość stanowi zwartą kompozycję graficzną dostosowaną do współczesnego pojmowania estetyki wydawniczej. Jej autorem jest artysta plastyk Włodzimierz Szyszka działający pod egidą Sztuki Polskiej [...]. Zależy nam na doskonaleniu komunikatywności wypowiedzi, podejmowaniu tematów prowokujących do przemyśleń. Pragniemy, aby każdy z Was drodzy Czytelnicy znalazł w swoim piśmie coś dla siebie, coś co go zainspiruje twórczo, aby „Głos Dolmelu” stał się Waszym pismem — dogodnym forum do wymiany myśli, poglądów i doświadczeń ${ }^{35}$.

Pełny skład redakcji został podany w 1982 roku. Byli to: Iwona Rubin (redaktor naczelna), Krystyna Bugielska, Stanisław Cetnarowicz, Jan Jędrzejowski, Tomasz Kapłon, Jan Krakowiecki (sekretarz), Antoni Kuczyński (przew. kolegium), Henryk Michalak, Jerzy Skwarek, Marian Spandel, Mirosław Stachowiak, Eugeniusz Szczerba, Kazimierz Urbanowicz. Redaktorem naczelnym od 1984 roku był Stanisław Stępień, a od 1986 roku - Andrzej Michalski.

W grudniu 1989 roku w obliczu nadchodzących zmian opublikowano tekst zatytułowany Jaki będzie?, w którym pisano:

Wiemy [...], że ten przejściowy okres niesie z sobą sporo zagrożeń i wymaga od nas niemało wyrzeczeń. [...] Nie wiadomo dziś przecież, ilu — za pół roku — spośród nas będzie musiało szukać innej pracy, przekwalifikować się, zmienić zawód? Jak ukształtują się relacje płac i cen, czy budżety domowe okażą się wystarczające? [...] Podobnych pytań stawiamy sobie wiele [...]. Tak jest zwykle, gdy dochodzi do zmian radykalnych, gdy trzeba sprostać wielkiej próbie czasu [...] $]^{36}$.

Od stycznia do maja 1990 roku gazeta ukazywała się w dużym formacie. Wydawano jeden numer miesięcznie o podwójnej numeracji (1-2 stycznia, 3-4 lutego,

34 T. Hubaj, Redakcja musi być na miejscu (dostownie i w przenośni), „Ku Nowemu” 1964, nr 5, s. 1-3.

35 Witamy w nowej szacie!, „Głos Dolmelu” 1987, nr 9, s. 1.

36 H. Michalak, Jaki będzie?, „Głos Dolmelu” 1989, nr 22-23, s. 1. 
5-6 marca, 7-8 kwietnia i 9-10 maja), utrzymując w ten sposób pozory częstotliwości dwutygodniowej. Nakład wynosił 3 tys. egzemplarzy, liczba stron -6 . Pozostałe ośmiostronicowe numery ukazały się już jako miesięcznik. Numery od 11 (817) do 17 (823) w nakładzie 3 tys. egzemplarzy (do września), w październi$\mathrm{ku}-2,8$ tys., a dwa ostatnie miesiące -2 tys. egzemplarzy. Powrócono też do małego formatu.

W artykule z numeru 17/1990, o wymownym tytule Do widzenia ...i dzień dobry, redakcja pisała:

Dziś, gdy po wielu latach „Dolmel” w dotychczasowym kształcie przestaje istnieć — zmiany, które dokonują się wokół nas, nie mogą ominą́ też i naszej gazety. [...] Co prawda, chcemy zachować to co najcenniejsze $\mathrm{w}$ dorobku gazety — zaufanie Czytelników, współpracę naszych wieloletnich korespondentów, ale też będziemy chcieli wywiązać się z nowych zadań. Otóż już na początku listopada chęć przejęcia funkcji naszego wydawcy (co jest sprawą nie tylko splendoru, ale i ponoszenia wydatków na utrzymanie pisma) wyraziły spółki ABB Dolmel i Dolmel Drives.

Zapowiadano, że w gazecie pojawi się więcej tekstów popularyzujących wiedzę zawodową, rozbudzających motywację do podnoszenia kwalifikacji. Pisano: „liczymy [...] na współpracę ze strony fachowców w różnych dziedzinach prowadzonej przez spółki działalności produkcyjno-gospodarczej”37. Mimo tych zapowiedzi „Głos Dolmelu” przestał się jednak ukazywać i prawdopodobnie nie był kontynuowany.

\section{5. ,ŻEGLARZ ODRZAŃSKI. ORGAN PRACOWNIKÓW ŻEGLUGI NA ODRZE” $(1954-1981)^{38}$}

Pierwszy numer gazety ${ }^{39}$ został wydany w listopadzie 1954 roku jako wynik poszukiwania sposobu na utrzymanie bieżącego kontaktu Komitetu Zakładowego PZPR, Rady Zakładowej i dyrekcji z pływającymi na barkach rzecznych pracownikami. Pierwszym redaktorem naczelnym był Adolf Grzybowicz, a redaktorem

37 Do widzenia ...i dzień dobry, „Głos Dolmelu” 1990, nr 17, s. 1.

38 W lipcu 1945 roku administrowanie Odrą przejął polski Komisariat Żeglugi na Odrze z siedzibą w Gliwicach, dokonując ewidencji holowników, barek i zalegających w rzece wraków. W 1946 roku powołano sp. z o.o. Polska Żegluga na Odrze z siedzibą we Wrocławiu i oddziałami w Gliwicach, Wrocławiu, Malczycach, Głogowie, Kostrzynie, Świnoujściu i Poznaniu. Zainaugurowano trasę odrzańską, prowadzono odbudowę portów, urządzeń przeładunkowych itp. W 1951 roku powstało Przedsiębiorstwo Państwowa Żegluga na Odrze z siedzibą we Wrocławiu i licznymi ekspozyturami; po wielu zmianach organizacyjnych przetrwało ono do 1990 roku. Po kolejnych prawnych i ekonomicznych przekształceniach w 1992 roku powstała spółka ODRATRANS SA, która rozwinęła transport międzynarodowy oraz własną bazę transportu rzecznego. Jest największym w Polsce i jednym z największych w Europie przewoźników zajmujących się żeglugą śródlądową. Odratrans $S A$, [hasło w:] $E W$, s. 608.

39 „Żeglarz Odrzański” w zasobie BUWr pod sygn. 28666 IV GŚŁ, zasób niekompletny: 1954-1958 oraz pod sygn. 31728 IV GŚŁ, zasób: 1965-1981. 
odpowiedzialnym Jerzy Owsiak, główny księgowy. Z czasem stronę techniczną przejął Tadeusz Emerling, wówczas depeszowy w „Słowie Polskim”. Pierwsza winieta zawierała kilka symboli: fale rzeki symbolizowały Odrę; nadlatujące z boku mewy — brzeg morza, do którego docierały barki Przedsiębiorstwa „Żegluga na Odrze". Dodatkowo z prawej strony umieszczano kotwicę, której sznur układał się w cyfrę 6 - symbol planu sześcioletniego; z lewej strony powiewała flaga armatora z wypisaną literą Ż. Winieta zmieniła się w 1958 roku - w centralnym miejscu można było oglądać sporą barkę, w którą wpisany był tytuł. Z prawej strony widniał emblemat „Żeglugi na Odrze”.

W 1960 roku pismo zlikwidowano, a w jego miejsce zaczęto wydawać biuletyn informacyjny. Kolejny numer w formacie B3 ukazał się dopiero w lipcu 1965 roku. Redakcja pisała wówczas:

wznawiamy wydawanie własnej gazety zakładowej dla załóg przedsiębiorstwa „Żegluga na Odrze". Nie jest to jednak start z punktu, w którym zatrzymaliśmy się wówczas. Nowa jest nie tylko winieta graficzna. [...] Szybciej niż wody odrzańskie płyną wydarzenia i przemiany. Z roku na rok stajemy się jako naród i państwo bardziej zasobni i nowocześni, ale i bardziej wymagający. Bierzemy to pod uwagę przy redagowaniu gazety, którą chcielibyśmy widzieć w Waszych rękach jako wypróbowanego informatora w interesujących Was sprawach, dowódcę w potrzebie, a nade wszystko lubianego i cenionego przyjaciela. [...] Chcemy by nic, co wodniackie nie było nam obce [...]. Wszyscy odczuwaliśmy brak tego wydawnictwa, które w warunkach żeglugowych zapewniało najszerszą więź załóg i bieżącą informację z ogólnego życia i pracy całego przedsiębiorstwa jak również charakterystykę ciekawych zjawisk i momentów ${ }^{40}$.

Informacje o kolegium redakcyjnym po raz pierwszy podano w 1965 roku. Redaktorem naczelnym był Adolf Grzybowicz, Wanda Agacka — redaktorem technicznym, Bolesław Kucharski - sekretarzem. Kolejnymi redaktorami byli: w 1966 początkowo Witold Samuel, potem Lucyna Kucza (do połowy 1974), następnie Grzegorz Szulejko, a w 1976 roku Tadeusz Sobieraj. Funkcję redaktora technicznego pełnił przez pewien czas Tomasz Setta, znany też z pracy przy gazecie „Elwro”.

Analiza częstotliwości ukazywania się gazety wykazuje, że do 1974 roku raz była ona dwutygodnikiem, raz miesięcznikiem, by ostatecznie ukazywać się jednak co dwa tygodnie. Zarówno przy małym, jak i dużym formacie nakład wahał się pomiędzy 1,2 tys. a 1,5 tys. egzemplarzy.

Tematyka była skupiona wokół spraw związanych z życiem PZPR, sojuszem z ZSRR, zagospodarowaniem Odry i Nysy jako granicy, współzawodnictwem pracy, działalnością kulturalno-oświatową. Bardzo dużo miejsca poświęcano przestrzeganiu zasad BHP. Pisano o zaopatrzeniu załóg pływających, o zimowych remontach śluz, o oszczędności paliwa. Pamiętano o Dniu Kobiet i Dniu Dziecka. W 1958 roku pisano, że ,przyjaźń Czytelników z pismem została zawarta, dowo-

40 Do Waszych rąk Czytelnicy, „Żeglarz Odrzański” 1965, nr 1, s. 1. 
dzi, że gazeta jest czytana - a więc potrzebna żeglarzom"41. Choć wymagania $\mathrm{z}$ biegiem lat wzrastały, to pozytywna opinia utrzymała się do ostatniego numeru z listopada 1981 roku. Nie wznowiono jej po ustaniu restrykcji stanu wojennego.

\section{6. „ŻYCIE ZAŁOGI. ORGAN KOMITETU ZAKŁADOWEGO PZPR PRZY WSK” $(1956-1981)^{42}$}

Pierwszy numer gazety ukazał się w lutym 1956 roku, zawierał cztery strony tekstu w małym formacie $(24,5 \times 35 \mathrm{~cm})$. Również ta winieta tytułowa zawierała dużo symboli, wśród których był skrót nazwy zakładów WSK (Wytwórnia Sprzętu Komunikacyjnego) ${ }^{43}$, koło zębate, cyrkiel, młot i gołąbek pokoju. Zniknęły one już w czerwcowym numerze, pozostawiając sam napis ze skrótem WSK.

Kolegium redakcyjne, którego składu nie podano, zwracało się do czytelników z prośbą o wyrozumiałość wobec ewentualnych błędów i niedopatrzeń, zapraszając do współpracy ,poetów, satyryków, amatorów fotografików, miłośników rozrywek umysłowych, rysowników". Wyrażano nadzieję, że dzięki temu „przyjęta [...] nazwa »Życie Załogi« będzie miała swoje pokrycie”. Podobnie jak $\mathrm{w}$ innych gazetach najważniejsze były tematy związane z życiem organizacji partyjnej i z produkcją. Na ostatniej stronie, nazwanej „Pod lupą życia”, znalazły się krzyżówki, sport, satyra i dowcipy. Na numerze 8 zakończyło się wydawanie gazety. Wznowiona została po 11 latach, w maju 1967 roku, z tym samym tytułem, ale w dużym, gazetowym formacie. Wydawana była jako dwutygodnik do stycznia 1980 roku, potem jako miesięcznik. Informowano, że ukazujący się do tej pory Biuletyn Informacyjny Komitetu Zakładowego został zawieszony, miał zbyt mały nakład i chyba nie wzbudzał wystarczającego zainteresowania, choć taka opinia nie padła wprost.

W winiecie tytułowej pojawił się rysunek siedzącego psa, z podpisem PSIE-POLE, co wyraźnie wskazywało na lokalizację zakładów. Pies zniknął z winiety w 1968 roku. Cała strona trzecia skierowana była do młodych pracowników. Gazetę redagował zespół w składzie: Jan Jarosz, Adam Kierbel, Eugeniusz Młynarski, Jadwiga Szafnicka, Krzysztof Trzciński (redaktor naczelny). Nakład w 1968 roku wynosił 2 tys. egzemplarzy. Od numeru 2 ze stycznia 1968 roku redaktorem na-

41 QUAS, Nad listami czytelników, „Żeglarz Odrzański” 1958, nr 3, s. 1.

42 „Życie Załogi” w zasobie BUWr pod sygn.31734 IV GŚŁ, zasób kompletny z lat 19561981.

43 Od 1946 roku główny producent precyzyjnych układów lotniczych: sterowań, napędów paliwowych i uzbrojenia oraz układów i wyrobów hydrauliki siłowej między innymi dla maszyn, obrabiarek, sprężarek. Jedyne na Dolnym Śląsku przedsiębiorstwo przemysłu obronnego. Od 1965 roku zakłady przechodziły kolejne zmiany o charakterze strukturalnym i technologicznym, odzwierciedlone w nazwie zakładu (1970-1974: Delta-Hydral; 1975-1993: PZL-Hydral; 1993: PZL-Hydral SA.). Hydral. Kombinat PZL-Hydral, [hasło w:] EW, s. 300. 
czelnym została Wanda Agacka, przewodniczącym kolegium - Władysław Kubański, a członkami: Longin Zabielski, Jan Jarosz, Eugeniusz Młynarski, Jadwiga Szafnicka, Krzysztof Trzciński. Skład ten, z małymi zmianami, utrzymał się do numeru 21 z 1972 roku. Nazwisko kolejnego redaktora naczelnego podano jednak dopiero w 1978 roku — był to Longin Zabielski, od początku obecny w składzie kolegium redakcyjnego, które było coraz liczniejsze ${ }^{44}$.

Podtytuł gazety, obrazujący następujące w niej przeobrażenia, zmienił się w czerwcu 1974 roku, gdy gazeta stała się organem Samorządu Robotniczego Kombinatu „DELTA-HYDRAL”. Przywrócono wówczas mały format i wydawano w nim gazetę do końca, to jest do listopada 1981 roku, w nakładzie 2,5-3 tys. egzemplarzy.

Omawiany tytuł był stosunkowo bogato ilustrowany fotografiami, na których widnieją urządzenia fabryczne, ale przede wszystkim brygady robotników, dzieci pracowników, młodzież zakładu, są widokówki z wakacji, a na koniec roku — tradycyjna „Szopka Noworoczna”. W treści znalazły się artykuły o pracy poszczególnych wydziałów produkcyjnych i ,wyzwalaniu ich mocy produkcyjnych", o racjonalizatorach, walce z brakami, o zobowiązaniach przedzjazdowych, spotkaniach załogi z władzami miasta i przedstawicielami rządu, o hufcach pracy. Pisano o rozwoju zakładu i nowych oddziałach (Strzelin) oraz kolejnych nowościach produkcyjnych, między innymi dla rolnictwa (pompy zębate, pompy wielotłoczkowe do kombajnów buraczanych, do zielonek i do ziemniaków). Były informacje o ośrodkach wypoczynkowych, wakacjach i zabawie sylwestrowej oraz działalności Klubu Motorowego PZL-Hydral. W numerze 19 z października 1981 roku donoszono o początkach prac Założycielskiego Samorządu Pracowniczego. Ostatni, 20 (423), numer gazety wydano w listopadzie 1981 roku.

\section{7. „NASZE PROBLEMY. CZASOPISMO SAMORZĄDU ROBOTNICZEGO ZZ ARCHIMEDES" (1969-1990) ${ }^{45}$}

Pismo w dużym, gazetowym formacie, $\mathrm{z}$ hasłem proletariackim nad tytułem, ukazało się 1 maja 1969 roku jako dwutygodnik powołany do życia decyzją Konferencji Samorządu Robotniczego Zjednoczonych Zakładów Archimedes ${ }^{46}$, w na-

${ }^{44}$ Byli to: Aleksander Cegliński, Marta Basta, Krystyna Drogosz (sekr.), Waldemar Gajowczyk, Jerzy Gere, Antoni Gryczman (przew.), Krystyna Jarosz (red. publ.), Wanda Jasiszczak (red. publ.), Magdalena Kokot, Henryk Kosowski, Irena Kuflińska (red. publ.), Władysław Markowicz, Eugeniusz Młynarski, Stanisław Sidor, Bożena Stępień (red. sprawozd.), Mieczysław Surma.

45 „Nasze Problemy” w zasobie BUWr pod sygn. 31886 IV GŚŁ, pełny zasób: 1969-1990.

46 Archimedes SA, fabryka śrub, która powstała jeszcze w 1875 roku. Po zakończeniu drugiej wojny światowej, w 1946 roku, na terenie zniszczonego zakładu ponownie uruchomiono produkcję śrub, potem nitów, maszyn śrubiarskich. Do lat 70. XX wieku trwała rozbudowa zakładu i rozszerzanie asortymentu. W 1963 roku zakończono produkcję wyrobów śrubiarskich, a w 1972 
kładzie 1,5 tys. egzemplarzy. Od sierpnia do stycznia następnego roku wychodziło jako miesięcznik i taka zmienność była charakterystyczna przez cały okres jego wydawania. Podany skład kolegium redakcyjnego zasadniczo nie zmienił się przez długi okres. Dla gazety pracowali: Zdzisław Swędzioł (redaktor naczelny), Rajmund Angnelius, Stanisław Borowy (zastępca przewodniczącego kolegium.), Mirosław Brzuska, Mieczysław Ciszowski, Zbigniew Dżusajew, Andrzej Oleśniewicz, Ludwik Szpunar. Od numeru grudniowego z 1972 roku redaktorem naczelnym była Monika Krasucka, od marca 1979 roku — Ewa Szumowska. Informacja o sposobie powołania gazety, życzenia od I sekretarza KW PZPR — Władysława Piłatowskiego, zamierzenia Redakcji — wszystko to znalazło się oczywiście w pierwszym numerze. Redakcja sporo uwagi poświęcała zakładowej młodzieży. Starano się, aby młodzi byli aktywni, z każdym rokiem coraz bardziej związani z zakładem, by doskonalili swoją wiedzę fachową. Na ostatniej stronie pisano o wakacjach („Nasi pracownicy na wakacjach”), turniejach międzyzakładowych, zamieszczano fraszki, konkursy, omawiano książki, wystawy organizowane w zakładowej bibliotece, od 1974 roku publikowano horoskopy. Od 1975 roku strona ta miała nagłówek „Wszystko dla wszystkich” i taka rzeczywiście była. W ostatnim roku wydawania gazety na stronie tej zagościły roznegliżowane, młode dziewczyny.

\section{8. „INTERMODA. ORGAN SAMORZĄDU ROBOTNICZEGO ZPO »INTERMODA«”} $(1972-1981)^{47}$

Zapowiedzią regularnie ukazującej się gazety zakładowej były dwie „Jednodniówki ZPO Intermoda Wrocław" z marca i maja 1972 roku w formacie 29,5 $\times 42 \mathrm{~cm}$, przygotowane przez zespół pod kierunkiem Andrzeja Lwa. Pisano o zadaniach, jakie postawił przed zakładami pracy VI Zjazd PZPR, o dyplomie uznania przyznanym załodze przez KC PZPR i Radę Ministrów. Sporo miejsca poświęcono bibliotece zakładowej, do której często wracano także w późniejszym okresie. Numer pierwszy ${ }^{48}$, będący pokłosiem wniosku zgłoszonego w dysku-

roku rozpoczęto licencyjną produkcję urządzeń udojowych firmy Alfa Laval. W 1976 roku zmieniono nazwę fabryki na Agrometr-Archimedes. Fabryka Maszyn Rolniczych. W latach 90. XX wieku nastąpiła komercjalizacja firmy. Archimedes $S A$, [hasło w:] $E W$, s. 38.

47 Intermoda. Zakłady Przemysłu Odzieżowego powstały w 1951 roku. Były wielozakładowym producentem ubrań męskich i młodzieżowych, marynarek oraz spodni dziecięcych, męskich i damskich, szytych przede wszystkim na eksport. Zakład powstał 1 stycznia 1950 roku i do 31 grudnia 1969 roku wszystkie jego oddziały mieściły się we Wrocławiu. Od stycznia 1970 roku w skład przedsiębiorstwa weszły zakłady w Lesznie i w Ostrowie. Od 1 lipca 1974 roku włączono także zakłady w Kamiennej Górze. Załoga liczyła w 1950 roku 1776 osób, a w 1975 ponad 4 tys. Zob. Intermoda, [hasło w:] EW, s. 309; Od Redakcji, „Intermoda” 1976, nr 1, s. 2.

48 Zarówno jednodniówki, jak i „Intermoda” w zbiorach BUWr pod sygn. 31940 IV GŚŁ, zasób: 1972-1981. 
sji przedzjazdowej i zaakceptowanego przez władze centralne, wyszedł 22 lipca 1972 roku w nakładzie 3,5 tys. egzemplarzy, a zredagował go zespół: Andrzej Michalski (redaktor naczelny), Andrzej Lew (sekretarz redakcji), Jacek Samotus (zdjęcia), Rajmund Klarzak (rysunki) ${ }^{49}$. Dwutygodnik Samorządu Robotniczego ukazywał się regularnie, liczył 4 lub 8 stron w numerach podwójnych, w formacie wymienionych jednodniówek lub większym $(37 \times 52 \mathrm{~cm})$. Nakład mieścił się przez cały czas w przedziale 4-4,7 tys. egzemplarzy. Winieta tytułowa nie zaskakiwała - był nią wyłącznie literowy tytuł. Sama gazeta była ilustrowana zdjęciami szytej odzieży, fotografiami najlepszych pracowników i coraz bardziej nowoczesnych maszyn.

Publikowane teksty dotyczyły oczywiście samego zakładu (współzawodnictwa, dbałości o coraz lepszą jakość, szukania rezerw, nowych maszyn do szycia). Przedstawiano „Ludzi dobrej roboty”, „Intermodę na zagranicznych rynkach”. Systematycznie pojawiały się różnego rodzaju zestawienia dotyczące wydajności pracy, gdzie podawano konkretny typ ubioru, na przykład spodnie czy marynarki, i wydajność liczoną w sztukach na godzinę oraz w liczbie braków na 10 tys. sztuk ${ }^{50}$. Bardzo ciekawy był drukowany cyklicznie „Mały słownik mody”. Obecne były oczywiście sprawy załogi, którą w ponad 84\% stanowiły kobiety uroczyście obchodzono w zakładzie i na stronach gazety Dzień Kobiet i Dzień Dziecka. Ostatnia strona przeznaczona była na różne informacje, czasem krzyżówki, często pojawiała się rubryka: „Co mówią i piszą o Intermodzie”, ogłaszano konkursy z nagrodami, na przykład na korespondencje do gazety: „Forma wypowiedzi dowolna: może to być reportaż, felieton, notatka. Zwracamy się do wszystkich: młodych i starszych, doświadczonych pracowników i tych, którzy stawiają pierwsze kroki w zawodzie - napiszcie do nas!" ${ }^{51}$. Sami pracownicy bardzo różnie oceniali swoją gazetę:

Ogólnie jest dobra. Może trochę za poważna, mało jest w niej rzeczy wesołych i humoru, [...] podawane tam informacje są niejako «przylizane» i nie odzwierciedlają meritum rzeczy. Ktoś nie pracujący w „Intermodzie” może odnieść wrażenie, że nie ma w naszym zakładzie spraw drażliwych i wszystko przebiega w rajskich warunkach. Bardzo liczyliśmy na gazetę jako płaszczyznę wymiany spostrzeżeń i opinii o sprawach właśnie drażliwych, których jest u nas bardzo dużo. Niestety, gazeta z niezrozumiałych mi powodów omija je. Mało jest także artykułów dla nas, kobiet [...]. Nie ma nic na temat opinii naszych odbiorców o szytej przez nas konfekcji [...]. Nie podoba mi się [...] przekręcanie niektórych faktów. Np. sprawa tulipanów. Zostały one dostarczone na naszą wyraźną prośbę u kontrolerów ubiorów z Holandii, a nie jako prezent właściciela wzruszonego jakością produkowanych u nas ubrań". [...] Jako kobieta proponuję do gazety wprowadzić kącik porad praktycznych" 52 .

49 W kolejnych numerach i latach nie podano nigdy innego składu.

50 Obszerne zestawienia nosiły nazwę: Tak pracowaliśmy w lutym..., Wyniki produkcyjne zespołów szwalniczych. Zob. między innymi „Intermoda” 1976, nr 5, s. 2; 1977, nr 14-15, s. 2.

51 Konkurs na korespondencję do gazety zakładowej, „Intermoda” 1976, nr 6-7, s. 6.

52 Fr. Saj, Gazeta czy sprawozdanie?, „Intermoda” 1973, nr 1, s. 3. 
Z mniejszymi lub większymi zastrzeżeniami czytelnicy kupowali swoją gazetę, której nakład w 1981 roku wynosił 4,1 tys. egzemplarzy, a więc niemal dokładnie tyle, ile było w „Intermodzie” zatrudnionych osób.

\section{9. „ELWRO. ORGAN SAMORZĄDU ROBOTNICZEGO. WROCŁAWSKIE ZAKŁADY ELEKTRONICZNE. DWUTYGODNIK" (1973-1981) ${ }^{53}$}

Poprzedniczką gazety było „Echo PN"54 — gazetka ścienna, a dokładnie sporej wielkości karton z barwnym rysunkiem i napisem „Nr 1 - maj 1967”. Łącznie ukazało się 13 numerów, a autorem tekstów i rysunków był Edmund Dubicki.

Pierwszy numer dwutygodnika „Elwro" 55 w nakładzie 2 tys. egzemplarzy ukazał się 15 marca 1973 roku w formacie $37 \times 52 \mathrm{~cm}$, o objętości czterech stron, w układzie sześcioszpaltowym. W deklaracji programowej zespołu redakcyjnego czytamy:

Adresujemy nasze pismo do czytelników — pracowników zakładu i ich rodzin. [...] Chcemy pomagać władzom zakładowym i wszystkim organizacjom w ich zamierzeniach. Chcemy informować o [...] pulsującym życiu zakładu [...] prezentować postawy godne naśladowania. [...] budzić poczucie dumy z osiągnięć pracy [...]. Chcemy, aby hasło „myśl i pracuj solidnie” — było naczelnym hasłem. [...] Chcemy [...] być waszą gazetą. Chcemy, by gazeta była pismem, o którym powiecie - nasza gazeta ${ }^{56}$.

List z gratulacjami do załogi i redakcji skierował I sekretarz Komitetu Dzielnicowego PZPR Zdzisław Miękina, który zwrócił uwagę na to, iż całe społeczeństwo realizuje wytyczne VI Zjazdu PZPR, a zakład Elwro ma w tych zadaniach odegrać istotną rolę polegającą na produkcji komputerów dla całego kraju. „W niełatwej realizacji Waszych planów - pisał - dopomoże założona z inicjatywy Komitetu Zakładowego PZPR i Samorządu Robotniczego — gazeta zakładowa. [...] Wierzę, że [...] stanie się [ona] aktywnym narzędziem krytyki społecznej

53 Zakłady Elektroniczne Elwro SA powstały w 1959 roku. Początkowo produkowały podzespoły radiowo-telewizyjne i automatyki przemysłowej. W 1963 roku Zakład uruchomił pierwszą seryjną produkcję maszyn cyfrowych własnej konstrukcji, dzięki czemu Wrocław stał się centrum przemysłu komputerowego w kraju. Słynne były w latach 60. XX wieku produkowane tu komputery II generacji Odra 1003, 1013, 1103, 1204 i maszyny cyfrowe do przetwarzania danych (Odra 1304). Lata 70. i 80. XX wieku przyniosły dalszy rozwój Zakładu i produkcję kalkulatorów elektronicznych, komputerów III generacji, maszyn cyfrowych, różnych urządzeń pomiarowych aż do mikrokomputerów profesjonalnych Elwro-801. W latach kryzysu gospodarczego końca lat 80. firma została sprywatyzowana i w 1993 roku zlikwidowana przez firmę Simens AG, właściciela akcji ZE Elwro. Zob. Elwro, [hasło w:] EW, s. 180.

54 Skrót PN oznaczał Wydział Ślusarsko-Montażowy.

55 „Elwro” w zasobie BUWr pod sygn. 31919 IV GŚŁ, pełny zasób: 1973-1989.

56 Od Redakcji, „Elwro” 1, 1973, nr 1, s. 1. 
w imię rozwoju zakładu"57. Z okazji powstania gazety i „przyjęcia jej do licznej rodziny pism zakładowych" 15 maja 1973 roku w ELWRO miała miejsce sesja wyjazdowa Dolnośląskiego Klubu Dziennikarzy Prasy Zakładowej. Obrady prowadził przewodniczący, red. Edward Bykowski z „Głosu Jelcza”58.

W pierwszym numerze znalazło się też ogłoszenie redakcji dotyczące tytułu: „Pierwszy numer nazwaliśmy po prostu »Elwro«. Skrót ten jest przecież popularny we Wrocławiu i znany w całym kraju. Chcielibyśmy jednak, aby o tak istotnej sprawie dla gazety, jak tytuł, zdecydowali czytelnicy [...]"59. Został rozpisany konkurs, nagroda pieniężna w wysokości 500 zł nie została jednak przyznana, ponieważ zgłoszone propozycje — zdaniem kolegium redakcyjnego — nie były odpowiednie. Tytuł pozostał, ale licznym zmianom ulegał podtytuł: w numerze 1 z 1977 roku brzmiał: „Dwutygodnik. Organ Samorządu Robotniczego Centrum Komputerowych Systemów Automatyki i Pomiarów Mera-Elwro", w numerze 16 tego roku dodano: „Magazyn Ilustrowany”, a dwa lata później, w numerze 14 z 1978 roku, informowano, iż jest on „Nagrodzony Złotą Szpilką 1975”60. Gdy w 1980 roku Centrum Komputerowych Systemów Automatyki i Pomiarów Mera-Elwro (CKSAiP Mera-Elwro) zostało odznaczone Orderem Sztandaru Pracy II Klasy, podtytuł rozbudowano, dodając do niego i tę informację ${ }^{61}$. Ostatnia zmiana, wprowadzona w numerze 2 z 1982 roku, przyniosła krótki podtytuł: „Pismo załogi ZE Elwro”.

Trzykrotnie (1973, 1977 i 1984) zmieniał się wygląd winiety, w której nazwa zakładu Elwro była sytuowana nieco odmiennie graficznie i kolorystycznie, ale zawsze zachowywała stylistykę charakterystyczną dla ówczesnych wydruków komputerowych. Jak wspomniano, gazeta ukazywała się co dwa tygodnie, choć numery podwójne nie należały do rzadkości i pojawiały się w okresie wakacji, świąt, przy specjalnych okazjach rocznicowych (XXX-lecie obrony cywilnej w PRL) i w okresie trudności finansowych. Początkowe 4 strony z czasem rozrosły się do 12-16. Zmiany dotyczyły także nakładu, który w 1975 roku wynosił 1,5 tys. egzemplarzy, w połowie 1977 roku wzrósł do 4 tys. W kolejnych latach wahał się w granicach 2,5-3 tys., by w 1989 roku zmniejszyć się do 1 tys. egzemplarzy.

Informacje na temat zespołu redakcyjnego podawano od czasu do czasu w stopce redakcyjnej. Początkowo p.o. redaktora naczelnego pełniła Wanda Aga-

57 Z. Miękina, Niech gazeta stuży załodze i gospodarce miasta, „Elwro” 1973, nr 1, s. 1.

58 Dziennikarze prasy zaktadowej w Elwro, „Elwro” 1973, nr 7, s. 2.

59 Ogłaszamy konkurs na tytuł gazety zakładowej, „Elwro” 1973, nr 1, s. 1.

60 Złota Szpilka - nagroda redakcji tygodnika satyrycznego „Szpilki” przyznawana corocznie za najlepsze rysunki w dwóch kategoriach: satyra i humor. W obu kategoriach przyznawano także „Srebrne Szpilki” i „Brązowe Szpilki”.

61 Ostatecznie pełny tytuł brzmiał: „Elwro. Dwutygodniowy Magazyn Ilustrowany Nagrodzony Złotą Szpilką 1975. Organ Samorządu Robotniczego CKSAiP Mera-Elwro odznaczonego Orderem Sztandaru Pracy II Klasy". 
cka, ale już w numerze 15-16 z 1973 roku podano pełny skład redakcji: Andrzej Michalski (redaktor naczelny), Wanda Agacka (sekretarz), Roman Kowalik (grafik) oraz Eugeniusz Stankiewicz; stali współpracownicy: Andrzej Teodorczuk, Eugeniusz Ziętkiewicz, fotoreporterzy: Wiesław Dębicki, Eugeniusz Jakubiak, Grzegorz Szustak. W 1979 roku naczelnym został Tomasz Setta (przez pewien czas na stanowisku sekretarza), rok później — Lubomir Stepach, a Setta ponownie w 1983 roku. Numery 1-22 z 1984 roku wyszły pod redakcją Mieczysława Lewickiego, a za kolejne odpowiadała Hanna Głowacka. Gdy w marcu 1983 roku świętowano 10. rocznicę istnienia gazety, jej ówczesny redaktor pisał:

Przyszliśmy do Elwro z różnych redakcji, różne reprezentowaliśmy szkoły dziennikarstwa, ale łączyło nas jedno: pragnienie robienia dobrego pisma [...]. Oprócz Czytelników, źródłem inspiracji zespołu dziennikarskiego było społeczne kolegium redakcyjne, w skład którego wchodzili przedstawiciele dyrekcji, organizacji polityczno-społecznych i naukowo-technicznych, ale przede wszystkim ludzie z wydziałów, reprezentanci robotników i ich interesów [...] $]^{62}$.

„Elwro” przestano wydawać po wprowadzeniu stanu wojennego, ale wznowiono po roku, w grudniu 1982 roku. W tekście czytamy: „Mamy świadomość, że wznawiamy wydawanie ELWRO w trudnej sytuacji. Nie do końca wygasły już wszystkie emocje spowodowane wydarzeniami zarówno sprzed roku, jak i wcześniejszymi czy późniejszymi. [...] Chcemy dawać świadectwo atmosferze pracy panującej w zakładzie"63. Reaktywowany tytuł ukazywał się jeszcze przez cztery lata.

Treść gazety w całym okresie ukazywania się była zgodna z deklaracjami zespołu redakcyjnego. Pisano o załodze i produkcji, wynalazczości i racjonalizacji, współpracy Elwro z innymi zakładami, publikowano wywiady z sekretarzami KZ i Komitetu Dzielnicowego PZPR, zamieszczano informacje z życia partii. Swoją stronę mieli ZMS oraz uczniowie szkoły przyzakładowej Elektronicznych Zakładów Naukowych. Regularnie ukazywały się informacje o nowościach biblioteki zakładowej, była moda i informacje dla pań, sport, turystyka, wypoczynek, krzyżówki, fraszki, humor oraz dowcipy w rubryce „Komputer by się uśmiał”. Zapraszano na przedstawienia do teatru, drukowano powieść kryminalną w odcinkach elwrowskiego autora Jacka Wiesława Witruka Szatan z miasta aniołów oraz Sprzedawca baśniowych miraży, w grudniu pojawiała się „Szopka Noworoczna”. Od 1974 roku na ostatniej stronie zaczęto zamieszczać zdjęcia roznegliżowanych pań. W odświętnej szacie - na grubym papierze z kolorowymi tytułami i fotografiami — ukazał się numer z okazji 25-lecia istnienia ZE Elwro.

Wyrażając opinie o gazecie, jej czytelnicy podkreślali, że ma być ona ,wizytówką przedsiębiorstwa”, życzyli sobie, by była przede wszystkim obiektywna.

62 Od redaktora, ,Elwro”, 11, 1983, nr 5, s. 1, 4.

63 Pragniemy nadal stużyć załodze!, „Elwro” 10, 1982, nr 1 (209) grudzień, s. 1-2. 
„»Woda« zbyteczna, bo wszyscy znają rzeczywistość [...] nie ma być laurką na zewnątrz”. Zwracano uwagę na jasny styl i zrozumiały język, bo choć ,,[...] duży procent załogi to ludzie z wyższym i średnim wykształceniem, gazeta powinna być czasopismem »dostępnym《 i zrozumiałym dla szerszego grona czytelników"64. $\mathrm{Z}$ czasem czytelnicy zgłaszali zapotrzebowanie na artykuły dotyczące historii Elwro, impresji z wyjazdów zagranicznych, popularyzacji światowych osiągnięć w dziedzinie informatyki, ale i informacji na temat mieszkań oraz porad lekarskich. Przeprowadzone w 1975 roku badanie popularności gazety wykazało, że aż $92,3 \%$ badanych uważało, że jest ona bardzo potrzebna; $w$ grupie badanych 91\% stanowiły kobiety, które argumentowały: „Kobieta współczesna, zwłaszcza pracująca, chce czytać i wiedzieć coraz więcej, aby w sposób świadomy i aktywny móc uczestniczyć w życiu polityczno-gospodarczym kraju" ${ }^{\prime 65}$.

\section{0. „POLAR. CZASOPISMO SAMORZĄDU ROBOTNICZEGO ZZSD »RREDOM- POLAR «"(1976-1981)}

Regularne wydawanie gazety przez kilka lat poprzedzały jednodniówki ${ }^{67}$, które ukazywały się od 1966 roku („Głos Zakrzowa. Jednodniówka Zakładów Metalowych »Polar«", „Polar. Jednodniówka Zakładów Metalowych »Polar«”), do 1969 roku zawsze 22 lipca. W 1970 roku jednodniówkę wydano 9 maja, z okazji 100 rocznicy „narodzin wielkiego Lenina, świętujemy w nim również pierwsze ćwierćwiecze istnienia naszej odrodzonej ojczyzny i rocznicę zwycięstwa nad faszyzmem" ${ }^{68}$. Nakłady tych jednodniówek były wysokie — sięgały prawie 7 tys. egzemplarzy.

Na regularnie wydawaną gazetę zakładową czekano jednak jeszcze 6 lat. Ukazała się ona 1 stycznia 1976 roku w dużym, gazetowym formacie, o objętości ośmiu stron, podwójnej numeracji i w nakładzie 2 tys. egzemplarzy. W układzie

64 Gazeta zakladowa? - Tak, ale jaka?, „Elwro” 1, 1973, nr 1, s. 3-4.

65 Gazeta w opinii załogi, „Elwro” 3, 1975, nr 10, s. 3, 5.

66 Zakłady Polar SA powstały w 1951 roku. Produkowano początkowo drobne części metalowe (wózki, łańcuchy), z czasem asortyment wzbogacono o chłodziarki absorpcyjne i pierwsze polskie motorowery. W 1972 roku nazwa Zakłady Metalowe została zmieniona na Zakłady Zmechanizowanego Sprzętu Domowego Predom-Polar. Rozwój zakładu postępował nieprzerwanie, specjalizacja dotyczyła sprzętu pralniczego, chłodziarek i chłodziarko-zamrażarek, kuchni mikrofalowych, okapów, sprzętu do zabudowy, zmywarek, piekarników, płyt grzewczych. Obecnie wyłącznym dystrybutorem marki Polar jest firma Whirlpool Polska SA. Polar SA, [hasło w:] EW, s. 687.

67 Zarówno jednodniówki, jak i właściwa gazeta „Polar” w zbiorach BUWr pod sygn. 31899 IV GŚŁ, pełny zasób: 1976-1981.

68 [Jednodniówka] Minęło 25 lat, „Polar” 9.05.1970, s. 1. 
graficznym winiety miejsce centralne zajmował napis POLAR, zgodny ze stylistyką, jaką stosowały zakłady na swoich produktach: białe litery na niebieskim tle. Drukowana była w Drukarni Technicznej Zakładów Radiowych „Unitra-Diora” w Dzierżoniowie. Zespół redakcyjny liczył 15 osób ${ }^{69}$, a najważniejsze stanowiska zajmowali: Christian Chudzik (redaktor naczelny), Henryk Kwolek (redaktor radiowęzła), Zbigniew Stanaszek (fotoreporter) i Katarzyna Święcka (grafik). Analiza tekstu redakcyjnego Tego chcemy ${ }^{70}$ zaskakuje, ponieważ jest on tożsamy z tekstem zamieszczonym w pierwszym numerze gazety „Elwro”. Identycznie brzmią też słowa skierowane do załogi przez I sekretarza KD PZPR Wrocław-Psie Pole - Henryka Gawrona ${ }^{71}$. Czyżby teksty były z góry przygotowane w komórkach partyjnych? Być może to za sprawą samej redakcji doszło do skopiowania tekstu innej gazety sprzed trzech lat? A może stało się tak dlatego, że ci sami ludzie pracowali czasami w redakcjach kilku gazet zakładowych, o czym świadczą na przykład nazwiska Wandy Agackiej, Andrzeja Michalaka czy Tadeusza Setty.

„Polar” - podobnie jak inne gazety — sporo miejsca poświęcał sprawom partyjnym, ale i niemało zagadnieniom produkcji, zwłaszcza wtedy, gdy na taśmę wchodziły nowe produkty będące sukcesem załogi, jak na przykład chłodziarka TS 135, której dotyczył niemal cały numer z lipca 1976 roku, czy też omawiano udział zakładu w kolejnych Międzynarodowych Targach Poznańskich. Pisano o tym, że najważniejszy jest klient i to w trosce o niego trzeba poprawić relacje miedzy fabryką a serwisem, przybliżano pracownikom, nowe wówczas, pojęcie marketingu, mówiono o bałaganie na terenie zakładu. Były numery, nie tylko na Dzień Kobiet, poświęcone kobietom, ponieważ stanowiły one w Polarze znaczną część załogi. W 1977 roku, świętując w gazecie Rok Biblioteki i Czytelnictwa, pisano o bibliotece w Młodzieżowym Domu Kultury Polar, o bibliotece zakładowej i jej zbiorach oraz o czytelnictwie robotników ${ }^{72}$. Znakiem czasu były informacje o NSZZ Solidarność oraz o Panoramie Racławickiej.

Gazeta wydawana była raz w miesiącu, w podwójnej numeracji, stwarzając tym samym pozory dwutygodnika. Nakład wynosił 3-3,5 tys. egzemplarzy. Ostatni numer ma datę 16 listopada 1981 roku.

${ }^{69}$ Cała redakcja jest przedstawiona w $\mathrm{nr} 3$ z 1980 roku na s. 6 w dowcipnym tekście: $A B C$ gazety zakladowej.

70 Tego chcemy, „Polar” 1976, nr 1, s. 2. Por. z przypisem 55.

${ }^{71}$ List gratulacyjny I sekretarza KD PZPR Wroctaw - Psie Pole Henryka Gawrona do Redakcji. Por. przyp. 56 i 57.

72 S. Straszewski, Jakim czytelnikiem książek jest robotnik?, „Polar” 1977, nr 22-23, s. 6. 


\section{1. „GŁOS ROKITY. ORGAN KOMITETU PARTYJNEGO, RADY ZAKŁADOWEJ, Z.M.P. I DYREKCJI"73 (1954-1981)}

Gazeta Nadodrzańskich Zakładów Przemysłu Organicznego (NZPO) „Rokita” w Brzegu Dolnym zaczęła się ukazywać w połowie 1954 roku $^{74}$. Uboga edytorsko, małego formatu $(21,5 \times 30,5 \mathrm{~cm})$, na czterech stronach tekstu informowała o zbliżającej się „konferencji partyjno-ekonomicznej”, opisywała Ogólnopolską Wystawę Wynalazczości i Postępu Technicznego, zapowiadała cykl wykładów dla pracowników. Czarno-biała winieta zawierała tylko literowy tytuł, nad którym umieszczone zostało hasło: „Proletariusze wszystkich krajów łączcie się!”. Jej nakład wynosił 1,5 tys. egzemplarzy. Wydawanie „Głosu Rokity” zostało stosunkowo szybko zawieszone. Przyczyną były narastające niepokoje społeczne, zwłaszcza konflikty płacowe, manifestacje i strajki trwające w zakładzie i w całym kraju już od połowy 1956 roku $^{75}$. Wznowiono ją w październiku następnego roku w większym formacie $(30 \times 43 \mathrm{~cm})$. Nowy podtytuł podkreślał, że jest to teraz pismo „Załogi N.Z.P.O.”; od 1966 roku natomiast był to „Organ Samorządu Robotniczego". Zniknęło też wówczas hasło proletariatu.

Starano się, by gazeta ukazywała się co 2 tygodnie, ale często wydawano ją z opóźnieniem lub jako miesięcznik, wiele razy z omyłkowo podaną numeracją. Publikowano w odcinkach powieść Henriego Beyle'a (Stendhala) Vanina Vanini, którą „z francuskiego przełożył inż. A. Groza”. Kolejna długa przerwa w wydawaniu gazety miała miejsce w 1958 roku — nie ukazywała się przez 7 miesięcy. Rok później wprowadzono nową winietę, w której postać diabła Rokity wkomponowana została w literę $\mathrm{G}$ - notabene w 1961 roku z niewiadomych powodów zmieniono jego lokalizację, przenosząc go do litery R. Format gazety utrzymał się do 1966 roku, potem przez kolejne cztery lata była wydawana w formacie pierwotnym, by w połowie 1970 roku znowu powrócić do dużego. Informacja o wysokości

73 W 1938 roku powstały w Brzegu Dolnym zakłady o nazwie „Anorgana”, które produkowały bojowe środki chemiczne, takie jak tabun i sarin, służące do napełniania bomb lotniczych i pocisków artyleryjskich. We wrześniu 1945 roku władze miasta przejęły od władz radzieckich zrujnowane i zdewastowane zakłady chemiczne. Decyzją ówczesnego Ministerstwa Przemysłu przystąpiono do odbudowy fabryki, dzięki czemu już w 1947 roku wyprodukowano podchloryn sodu i chlorek siarki. W czerwcu tego roku zmieniono poniemiecką nazwę zakładów na „ROKITA”. Mocą zarządzenia Centralnego Zarządu Przemysłu Chemicznego w Łodzi w 1949 roku zostały utworzone Nadodrzańskie Zakłady Przemysłu Organicznego „Rokita” w Brzegu Dolnym. 1 kwietnia 1992 roku po zmianach ustrojowych firma stała się jednoosobową spółką skarbu państwa i zmieniła nazwę na Zakłady Chemiczne Rokita S.A. Od 1 kwietnia 2010 roku Grupa PCC SE jest jedynym udziałowcem (właścicielem) przedsiębiorstwa. Por. https://pl.wikipedia.org/wiki/ PCC_Rokita [dostęp: 3.11.2018].

74 „Głos Rokity” w zasobie BUWr, pod sygn. 31191 IV GŚŁ, zasób niekompletny obejmuje lata $1954-1981$.

75 Redakcja zamieściła obszerny artykuł na ten temat — Niewłaściwa droga, „Głos Rokity” 1957, nr 2, s. 1-2. 
nakładu była podawana rzadko — po raz pierwszy w 1964 roku podano, iż jest to 1 tys. egzemplarzy. Nakład wzrastał w kolejnych latach do 2 tys., a nawet do 3 tys. egzemplarzy w 1979 roku, aby w roku następnym zmaleć do 1,5 tys. egzemplarzy.

Nazwisko redaktora odpowiedzialnego - L. Jurgowiaka — pojawia się pierwszy raz w listopadzie 1966 roku, zdjęcia robił R. Czuchajewski; od 1977 roku redaktorem naczelnym był Władysław Dukiet.

Określając tematykę gazety ${ }^{76}$, trzeba powiedzieć, że także i w niej pierwsze dwie strony przeznaczone były na sprawy związane z polityką partii i państwa. Interesowano się oczywiście sprawami zakładu (ekonomicznymi, produkcyjnymi, socjalnymi i kulturalnymi), omawiano regulamin pracy, w tym zwłaszcza BHP, kartę praw obywatela, udzielano porad prawnych, pisano o zaopatrzeniu sklepów, o koloniach i wczasach (budowa domu wczasowego w Pogorzelicy), o sytuacji w zakładowym żłobku, przedszkolu i domu kultury. Była rubryka poświęcona młodym pracownikom. Ostatnią stronę, jak wszędzie, charakteryzował lżejszy styl wypowiedzi. Redakcja starała się reagować na sygnały o nieprawidłowościach, na przykład w numerze 5 z 1959 roku ukazała się notatka o złych praktykach w żłobku, ale... już w kolejnym numerze, zapewne w celu uspokojenia rodziców, na pierwszej stronie zamieszczono zdjęcie szczęśliwych maluchów. Wielokrotnie zapraszano czytelników do współpracy. Gdy „Głos Rokity” w 1977 roku został odznaczony Złotą Odznaką Honorową Związku Zawodowego Chemików, redaktor Dukiet pisał:

Jesteśmy jedną z nielicznych redakcji, których praca oceniona została tak wysoko. [...] W osiąganiu celów wytyczonych przez partię na etapie budowy rozwiniętego społeczeństwa socjalistycznego gazeta nasza ma do spełnienia ważną rolę, zarówno w systemie informacji wewnętrznej w „Rokicie”, jak też dla unaocznienia załodze znaczenia i stopnia trudności stawianych przed nią zadań [...]. Oceny, którymi poddany był w tym roku „Głos Rokity” stwierdzały, że wśród publikacji za mało jest głosów pochodzących od załogi. Czyżby nasza załoga i inni czytelnicy nie mieli żadnych problemów, nad którymi warto się wspólnie zastanowić? ${ }^{77}$.

W 1981 roku gazeta wychodziła bardzo nieregularnie. Ostatni numer 10 (492) ukazał się w listopadzie.

\section{2. „GŁOS JELCZA. ORGAN SAMORZĄDU ROBOTNICZEGO” (1962-2001)}

Regularne ukazywanie się gazety zostało poprzedzone wydaniem dwóch jednodniówek. Pierwsza, „Głos Jelcza. Jednodniówka Samorządu Robotniczego. Wydanie z okazji X-lecia Zakładów", ukazała się 10 lutego 1962 roku. Były to cztery strony, w formacie $35,5 \times 51 \mathrm{~cm}$. Nie było informacji o kolegium redakcyjnym

76 Pełnym opracowaniem tego tytułu i jego zawartości treściowej jest praca B. Koredczuk, op. cit.

77 W. Dukiet, Duży zaszczyt dla „,Głosu Rokity”, „Głos Rokity” 1977, nr 6, s. 1. 
i o nakładzie. Pisano między innymi o oddziałowych organizacjach partyjnych, poprawie warunków socjalnych, normach technicznych, wnioskach racjonalizatorskich. Numer drugi, z marca, o takim samym tytule, liczył sześć stron. Podano w nim skład kolegium. Byli to: Jerzy Rutkowski (przewodniczący), Zbigniew Świnarski (sekretarz), Stanisław Grzegorzewicz, Marian Dudek, Jerzy Podlak, Zbigniew Błażewicz, Zbigniew Piskozub, Lesław Idzikowski, Zdzisław Zaniewski. Na stronie pierwszej redakcja zamieściła artykuł o charakterze wspomnieniowym Już 10 lat!, pisząc, że to dzięki decyzji Prezydium Rządu zostały powołane do życia Jelczańskie Zakłady Samochodowe ${ }^{78}$, które „od małej fabryczki drewnianych samochodów przeobraziły się w wielkie przedsiębiorstwo". Artykuły dotyczyły kwestii socjalnych, w tym dwóch jelczańskich osiedli mieszkaniowych, gdzie warunki życia autor określił jako bardzo trudne. Opublikowano też regulamin punktowy przydziału mieszkań, zamieszczono zdjęcia pracowników z wczasów nad Balatonem oraz ze szpitala, gdzie przedstawiciele władz partyjnych, związkowych i dyrekcji zakładów odwiedzili chorych pracowników.

Pierwszy numer „Głosu Jelcza. Organu Samorządu Robotniczego” ukazał się 1 maja 1962 roku $^{79}$. Winieta tytułowa była skromna - na kolorowym tle widniał tylko napis literowy. Dopiero od numeru 4 z 1971 roku w literę G wpisano symbol ZZM (Związku Zawodowego Metalowców), zastąpiony w numerze pierwszym z 1982 roku napisem ,30-lecie”, a w 1987 roku — symbolicznym wizerunkiem odznaczenia „Zasłużony dla woj. wrocławskiego i Wrocławia”.

Gazeta wychodziła raz na miesiąc. Od listopada 1964 roku redaktorem naczelnym mianowano Wandę Agacką. Pozostałymi członkami kolegium byli: Jan Brochowski, Tadeusz Gawroniuk, Bronisław Jucha, Edward Bykowski, Kazimierz Rosiewicz, Michał Smektała, Michał Szczupak (sekretarz), Zbigniew Świnarski (przewodniczący) Włodzimierz Konrad, Tadeusz Stoiński, Michał Semaniuk, Ryszard Wyganowski, Józef Soroka. Od numeru 22 z 1968 roku w składzie redakcyjnym nie było już Agackiej, podano tylko, że sekretarzem jest Edward Bykowski, a Świnarski — przewodniczącym. Nazwisko Bykowskiego jako redaktora naczelnego podano w 1970 roku — prowadził on „Głos” aż do 1995 roku, to jest do momentu, kiedy zastąpił go Jerzy Smyk.

78 Powstały w 1952 roku pod nazwą Zakłady Budowy Nadwozi Samochodowych. Mieściły się wówczas w starej i zniszczonej poniemieckiej hali zbrojeniowej. W zakładach tych opracowywano i produkowano różnorodne nadwozia przystosowane do montażu na ramach samochodów FSC Lublin i Star. W 1958 roku Zakłady Budowy Nadwozi Samochodowych połączyły się z Zakładami Naprawy Samochodów w Jelczu. Powstałe w ten sposób przedsiębiorstwo przyjęło nazwę Jelczańskie Zakłady Samochodowe. Dzisiaj jest to znany w całej Polsce producent autobusów, pojazdów wojskowych i ciężarowych, a także przedsiębiorstwo motoryzacyjne. Siedziba spółki znajduje się w Jelczu-Laskowicach. Por. http://pl.transport.wikia.com/wiki/Jelcza\%C5\%84skie_ Zak\%C5\%82ady_Samochodowe [dostęp: 3.11.2018].

79 „Głos Jelcza” w zasobach Dolnośląskiej Biblioteki Publicznej im. Tadeusza Mikulskiego we Wrocławiu. Zasób za lata 1962-2001, niektóre roczniki niekompletne. 
Pierwszy raz informacje o nakładzie podano w 1965 roku -2 tys. egzemplarzy. Pięć lat później wynosił on 2,5 tys. egzemplarzy; od 1973 roku oscylował pomiędzy 3,5 tys. a 3,6 tys.; w 1975 roku, podobnie jak w innych gazetach, wzrósł do 4,5 tys. egzemplarzy i utrzymywał się na tym mniej więcej poziomie do końca lat 90. XX wieku. Ostatni numer z 20 września 2001 roku ukazał się w nakładzie 2,3 tys. egzemplarzy. Częstotliwość zmieniła się od numeru 18 z 1999 roku, odkąd gazeta zaczęła wychodzić jako tygodnik.

Omawiając treść tej gazety w całym okresie ukazywania się, trzeba powiedzieć, że i ona nie odbiegała od innych. Uwagę zwracał felieton publikowany w rubryce „My oławianie”, w którym to przez cały okres ukazywania się gazety poruszane były najważniejsze problemy mieszkańców Oławy i Jelcza. Od 1973 roku co dwa tygodnie na jej łamach przedstawiani byli zasłużeni i cenieni pracownicy przedsiębiorstwa wraz z rodzinami. Sporo miejsca poświęcano prototypom nowych samochodów, na przykład Fiata 126p, czy Berlietom - autobusom wyprodukowanym we współpracy z Francuzami. W Zakładach Jelczańskich propagowano sport i własnych zawodników - pisano o ciężarowcach, bokserach, motocyklistach, o Rajdzie Paryż-Dakar, w którym jechał ich samochód ciężarowy. Zainteresowaniem cieszyły się też rubryki, na przykład: „Nasze sylwetki”, „Najlepsi racjonalizatorzy”, „Nasi aktywiści”, „Nasi sportowcy”. Gazeta wydawana była się nieprzerwanie do listopada 1981 roku, powróciła po czterech miesiącach, w kwietniu 1982 roku, i ukazywała się nadal, przechodząc bez większych problemów kolejne zmiany w zakładzie. Od 1991 roku do 2001 roku drukowano ją w małym formacie $(21 \times 29,8 \mathrm{~cm})$. Miała też swój numer ISSN 14285819.

\section{PODSUMOWANIE}

Gazety zakładowe odzwierciedlają panujący w okresie rządów komunistycznych w Polsce system odgórnego kierowania prasą, zarówno w zakresie ich form organizacyjnych, składu personalnego, jak i poruszanej na ich łamach tematyki.

W sprawach organizacyjnych sterowany był przede wszystkim skład kolegiów redakcyjnych, na których czele musieli stać: sekretarz KZ PZPR, członkowie KZ, przedstawiciele ZMS i dyrekcji. Systematycznie organizowano narady i szkolenia redaktorów w zakresie spraw warsztatowych, ale przede wszystkim w sprawach ideologicznych, w kierunku pogłębienia znajomości zagadnień politycznych, gospodarczych i społecznych. Redaktorzy gazet zakładowych musieli brać udział w spotkaniach i seminariach organizowanych przez Stowarzyszenie Dziennikarzy Polskich, WRZZ, Wydział Pracy Ideowo-Wychowawczej odpowiedniego szczebla PZPR. Dążono do zorganizowania sieci doświadczonych i zaufanych korespondentów zakładowych. 
W zakresie realizowanych tematów określano najważniejsze zagadnienia, które musiały znaleźć się w gazecie, a odnoszące się do:

a) aktualnej sytuacji w kraju, postrzeganej z punktu widzenia przodującej roli PZPR i współpracy gospodarczej z ZSRR (konferencje sprawozdawczo-wyborcze, plena KC PZPR, zjazdy, produkcja eksportowa);

b) przodującej roli zakładowej organizacji partyjnej i jej członków (na przykład w rubrykach „Portrety ludzi partii”, „Moja droga do partii”);

c) szerokiej informacji o bieżących zadaniach produkcyjnych zakładu, relacji z narad wytwórczych, o aktualnych problemach załogi, projektach racjonalizatorskich, wynikach współzawodnictwa;

d) edukacji załóg w zakresie doskonalenia produkcji (publikowanie tabel i różnych zestawień dotyczących wybrakowanych produktów, ale i wyników produkcyjnych);

e) popularyzacji znajomości prawa i kodeksu pracy;

f) dążenia do stworzenia i utrzymania właściwego klimatu w pracy, przestrzegania zasad wzajemnego poszanowania (na przykład zamieszczano przeprosiny za przejawy niewłaściwego zachowania), dbałości o porządek, walki z bumelanctwem (zdjęcia takich pracowników publikowano wraz z informacją o przewinieniu i nałożonej karze), zapobiegania marnotrawstwu, piętnowania złych zachowań i nagradzania najlepszych pracowników (tu także publikowano zdjęcia w specjalnych rubrykach „Kolumna Honoru”, „Nasi Najlepsi”);

g) zachęcania do podnoszenia kwalifikacji zawodowych (stała informacja między innymi o nowych nabytkach biblioteki zakładowej) i korzystania z oferowanych form rozrywki i wypoczynku.

Do najważniejszych funkcji realizowanych przez omawiane gazety należały: wpływanie na kształtowanie postaw pracowników, motywowanie do odpowiedniej aktywności i podejmowania wyzwań związanych ze współzawodnictwem, racjonalizacją, a także ukazywanie sukcesu zawodowego i awansu społecznego (funkcje: agitacyjno-propagandowa oraz kontrolna, perswazyjna, motywacyjna, opiniotwórcza). Realizacja funkcji edukacyjno-wychowawczej, integracyjnej czy rozrywkowej polegała na dostarczaniu wiedzy o otaczającej rzeczywistości związanej z zakładem pracy, wyzwalaniu satysfakcji z przynależności do niego - lub nieco szerzej - do danego osiedla czy miasta, integrowaniu środowiska pracy z otoczeniem prywatnym, kształtowaniu wzorców postępowania, dostarczaniu rozrywki.

W badanym materiale zwracają uwagę powtarzające się nazwiska niektórych redaktorów - szczególnym przypadkiem jest Wanda Agacka pracująca w niemal wszystkich redakcjach. Można przypuszczać, że w ten sposób wykorzystywano jej doświadczenie zawodowe, które pozwalało „ustawić” daną gazetę, wskazać współpracownikom zasady pozyskiwania informacji i przygotowania jej do 
opublikowania. Warto też zauważyć, że gazety były odpłatne (ceny raczej niskie, symboliczne), co regulowała Uchwała Prezydium CRZZ o Zasadach Organizacji i Działalności Gazet oraz Radiowęzłów Zakładowych z 15 stycznia 1974 roku$^{80}$. Chociaż gazetę zakładową możemy uważać za relikt epoki, to jednak należy pamiętać, że dla pracowników była ona ważnym elementem kształtowania ich tożsamości, budowała poczucie wspólnoty nie tylko przez podawanie wyników produkcyjnych, lecz także dzięki relacjom z zawodów sportowych, w których sami uczestniczyli, dbaniu o ośrodki wczasowe, które często sami budowali, prezentowaniu własnej twórczości różnego rodzaju. Dzisiaj te gazety pozostają niezastąpionym źródłem wiedzy o zakładach, które często już nie funkcjonują, czasami wręcz o naszych rodzinach, związanych z tym czy innym miejscem pracy w regionie dolnośląskim.

\section{BIBLIOGRAFIA}

\section{ŹRÓDŁA}

Archiwum Państwowe we Wrocławiu. Zespół KW PZPR we Wrocławiu. Wydział Propagandy, sygn. 965, 970, 2716, 2753, 2754

„Ruch Wydawniczy w Liczbach” 14, 1969-38, 1992

TYTUŁY GAZET ZAKŁADOWYCH:

„Głos Dolmelu” zob. „Ku Nowemu”

„Głos Jelcza” (1962-2001)

„Głos Rokity” (1954-1981)

„Elwro” (1973-1981)

„Intermoda" (1972-1981)

„Ku Nowemu” (1954-1990)

„Nasze Problemy” (1969-1990)

„Pafawag” (1946-1990)

„Polar” (1976-1981)

„Żeglarz Odrzański” (1954-1981)

„Życie Załogi” (1956-1981)

80 Ile kosztuje gazeta?, „Intermoda” 1974, nr 14-15, s. 2. Przedstawiono czytelnikom kalkulacje kosztów wydawania gazety zakładowej na podstawie tej właśnie uchwały. Czytamy: „Wydajemy gazetę już trzeci rok. Koszty są wysokie. Druk jednego numeru łącznie z papierem kosztuje 800 zł. Należy do tego jeszcze doliczyć koszty honorariów 3000 zł plus nasze etaty około $6500 \mathrm{zł}$. Da nam to jednorazowy koszt rzędu $17500 \mathrm{zl}$, co pomnożone przez 24 numery w roku wyniesie 420 tys. [...] Wprowadzenie odpłatności nie ma za zadanie pokrywać owej prawie półmilionowej kwoty. Chodzi tylko o to, aby z prenumeraty można było opłacić honorarium autorów piszących do gazety oraz skromnie wynagrodzić przyszłych jej kolporterów. Suma jaką miałby w ciągu roku zapłacić za gazetę pracownik, wynosi 24 zł, czyli jeden egzemplarz 1 złotówkę". 


\section{OPRACOWANIA}

Banaszek M., Polska prasa zakładowa (funkcje, charakterystyka, klasyfikacja i periodyczność, „Kwartalnik Historii Prasy Polskiej” 25, 1986, nr 2, s. 53-68.

Biel T., Z dziejów wielkopolskiej prasy zakładowej, „Kronika Wielkopolski” 1984, nr 1, s. 99-127.

Cukierberg L., Doświadczenia w pracy z gazetkami ściennymi, „Prasa Polska” 1950, nr 8-9, s. 27.

Dziki T., Prasa zakładowa i międzyzakładowa we Włocławku w latach 1945-2002, [w:] Media lokalne i sublokalne na Kujawach wschodnich i ziemi dobrzyńskiej, pod red. W. Końskiego, Włocławek 2007, s. 75-95.

Karpowicz R., W sprawie genezy i rozwoju prasy zakładowej, „Prasa Polska” 1976, nr 7-8, s. 31-32.

Kępa J., Twórcy prasy zakładowej Kielecczyzny (1945-1989), „Kieleckie Studia Bibliologiczne” 4, 1998, s. 151-167.

Koredczuk B., Pismo zakładowe „Głos Rokity” (1951-1981) jako źródło informacji o Brzegu Dolnym, [w:] Brzeg Dolny. Dzieje wybranych instytucji i zagadnień, pod red. J. Koredczuka, t. 2, Brzeg Dolny 2017, s. 249-280.

Kupis T., Prasa zaktadowa elementem systemu prasowego, „Prasa Polska” 1977, nr 9, s. 19-21.

Pelczarski B., Prasa zakładowa regionu kielecko-radomskiego, „Zeszyty Naukowe Politechniki Świętokrzyskiej. Nauki Społeczno-Ekonomiczne" 18, 1988, s. 139-148.

Pisarek W., Skowroński A., Świda A., Raport o prasie zakładowej, „Zeszyty Prasoznawcze” 1978, nr 1, s. 75-86.

Rakowski M., Prasa fabryczna w Planie Sześcioletnim, „Prasa Polska” 1950, nr 8-9, s. 11.

Słomkowska A., Z badań nad dziennikarstwem Polski Ludowej, ,Rocznik Historii Czasopiśmiennictwa Polskiego" 15, 1976, z. 3, s. 319-334.

Świda A., Prasa zakładowa w okresie przemian, ,Zeszyty Prasoznawcze” 22, 1981, nr 1-2, s. 27-40.

Świda A., Raport o prasie zakładowej. II (Próba bilansu ostatnich pięciu lat), „Zeszyty Prasoznawcze" 24, 1983, nr 2, s. 17-35.

Turlik-Marecka J., Sobczak J.B., Rola i funkcje prasy zakładowej w Polsce, Kraków 1975.

\section{INFORMATORY}

Encyklopedia wiedzy o prasie, pod red. J. Maślanki, Wrocław 1976.

Encyklopedia Wrocławia, pod red. J. Harasimowicza, Wrocław 2006.

\section{MAŁGORZATA KORCZYŃSKA-DERKACZ}

\section{FROM THE PRESS HISTORY OF THE LARGEST INDUSTRIAL PLANTS IN WROCŁAW AND THE SURROUNDING AREA (1946-1990)}

\section{Summary}

The author presents a historical overview of company newspapers published in Wrocław and two nearby towns - Brzeg Dolny and Jelcz-Laskowice - where large industrial plants employing thousands of people living in the Lower Silesian capital were located. The article consists of two parts. In the first the author quotes the definition of company press, discusses its function and on the basis of figures from Ruch Wydawniczy w Liczbach [Polish Publishing in Figures] from 1968-1992 presents the publication frequency and geography of such publications with regard to the whole country. Part two is devoted to company newspapers published in the region referred to in the title. Drawing on an analysis of archive material kept in the State Archives in Wrocław, especially documents produced by the Regional Committee of the Polish United Workers' Party in 1971-1978, the 
author examines the party nature of these publications and the requirements imposed on their editorial teams. She analyses the following publications in chronological order: Pafawag (1946-1990), Ku Nowemu (1954-1990), Żeglarz Odrzański (1954-1981), Życie Załogi (1956-1981), Nasze Problemy (1969-1990), Intermoda (1972-1981), Elwro (1973-1981), Polar (1976-1981), as well as one from Brzeg Dolny (Glos Rokity, 1954-1981) and Jelcz-Laskowice (Głos Jelcza 1962-2001). She points to formal features like format, size and circulation; editorial features, especially changes in the graphic layout of the headpiece; lists members of the editorial teams and briefly describes the profile of each newspaper in question.

KEY WORDS: company newspapers, party press, regional and local press, Wrocław, Lower Silesia, Głos Jelcza, Głos Rokity, Elwro, Intermoda, Ku Nowemu, Nasze Problemy, Pafawag, Polar, Żeglarz Odrzański, Życie Załogi 